
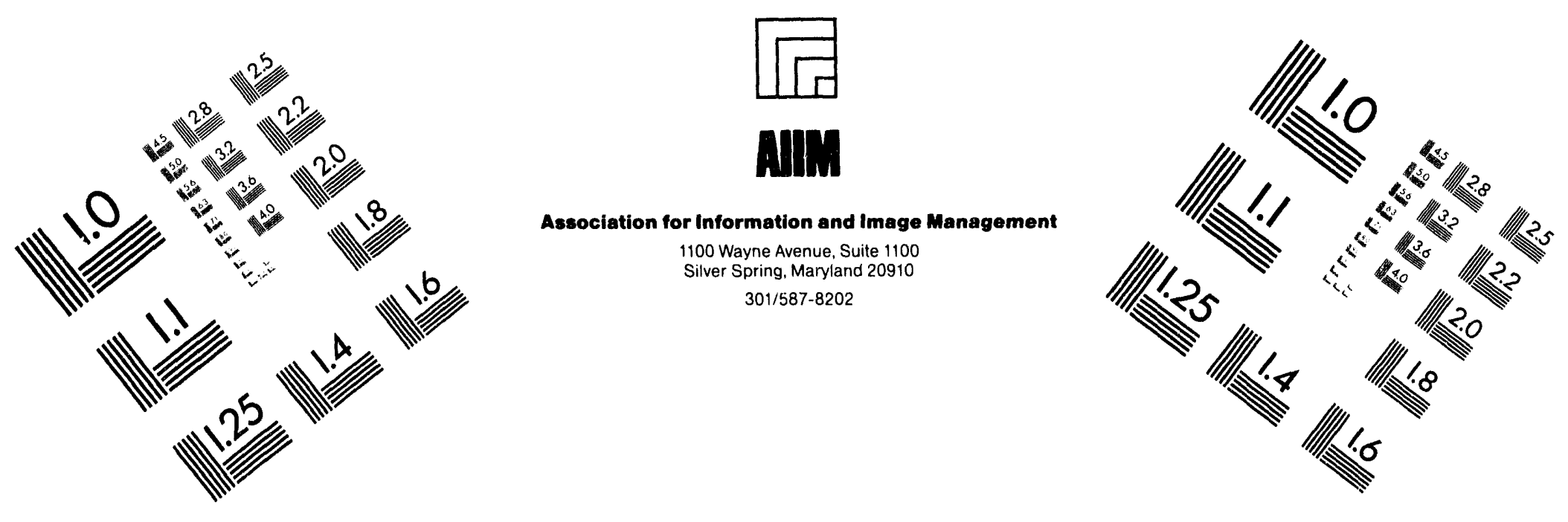

\title{
Centimeter
}

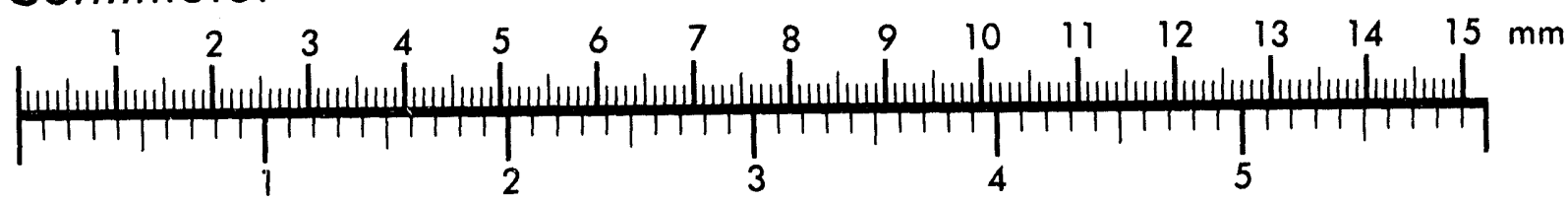
Inches
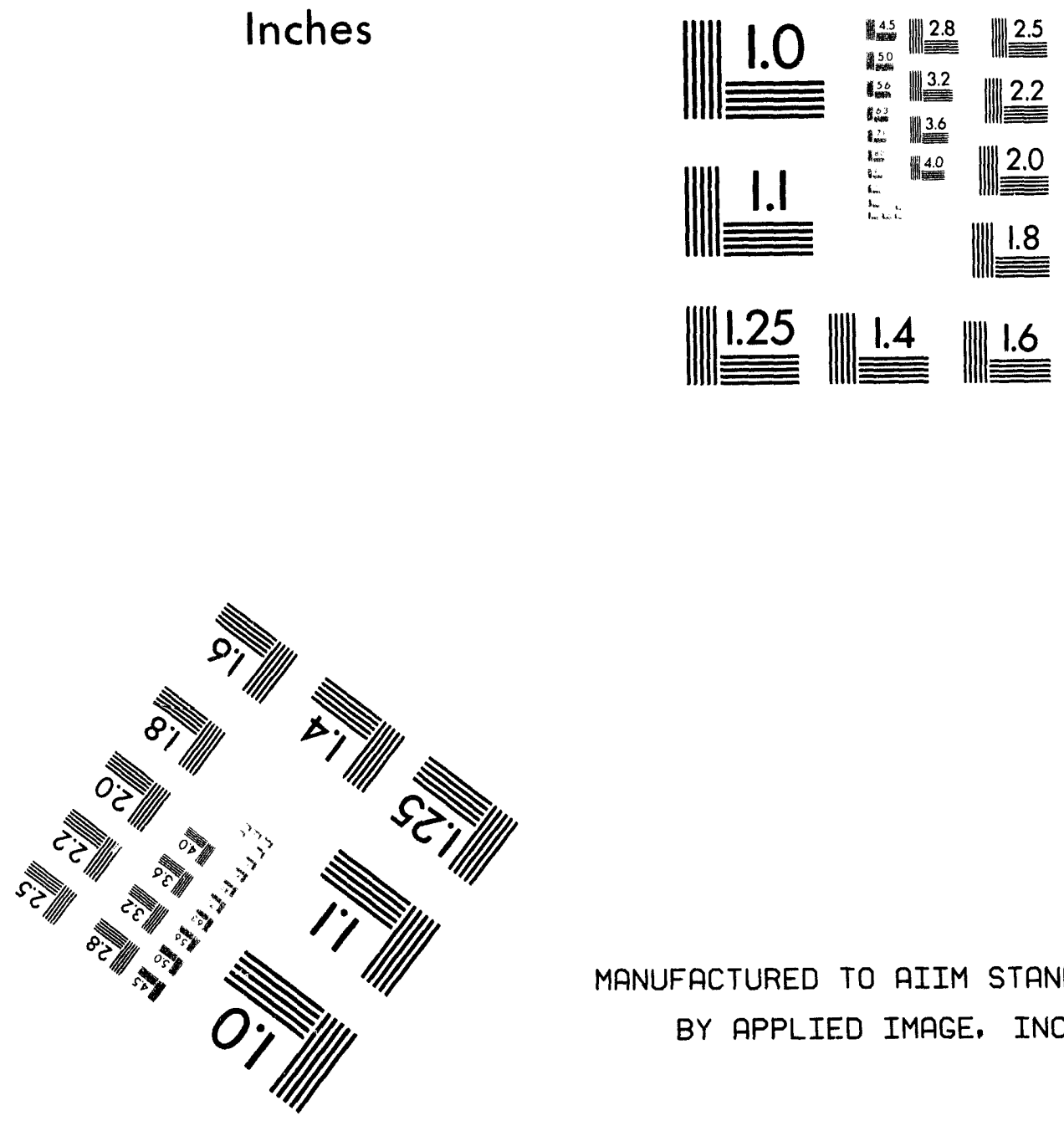

MANUFACTURED TO AIIM STANDARDS

BY APPLIED IMAGE. INC.

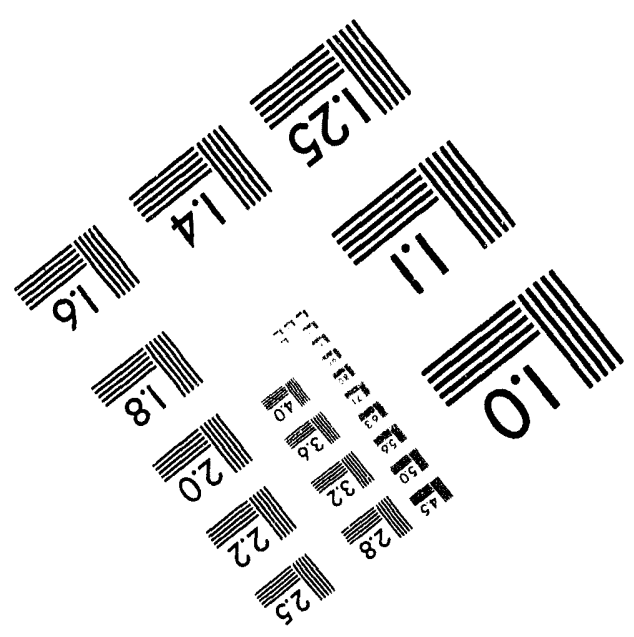



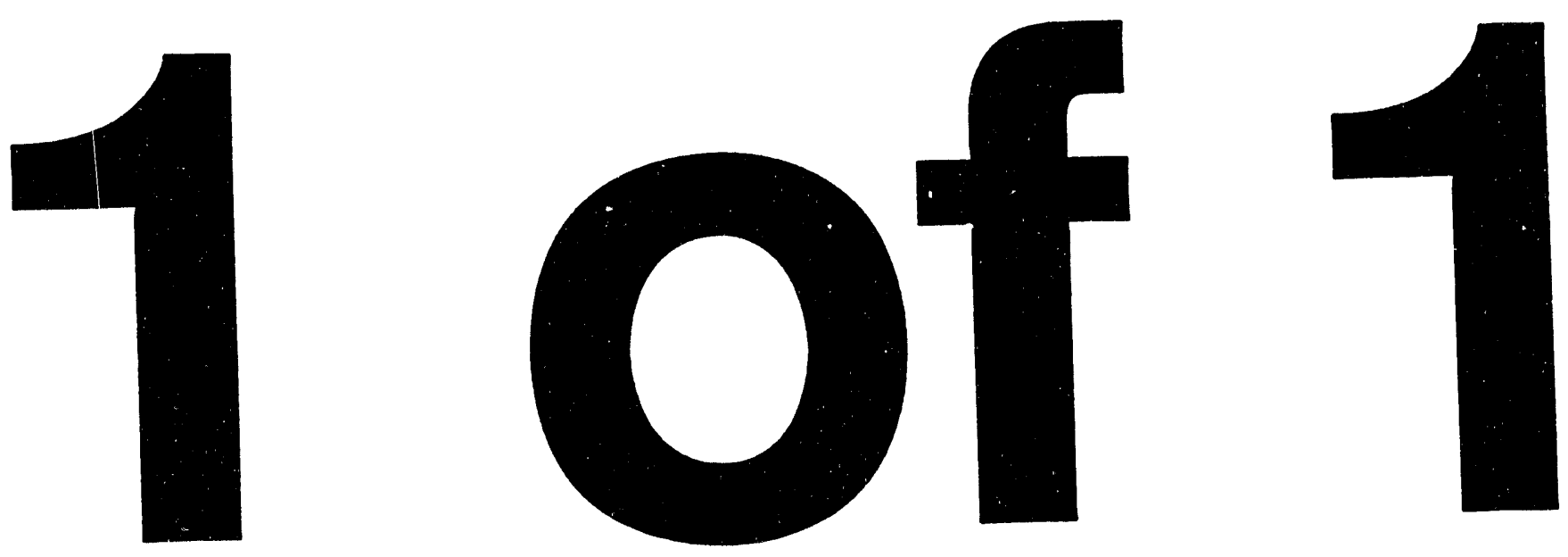


\section{Quantitative and Qualitative Analysis of Some Inorganic Compounds by Raman Spectroscopy}

Prepared for the U.S. Department of Energy Office of Environmental Restoration and Waste Management

\section{(W) Westingtrouse P.O. Box 1970}

W. Hanford Company P.O. Box 1970 Rand, Washington 99352

Hanford Operations and Engineering Contactor for the

U.S. Department of Energy under Contract DE.AC06.87RL 10930

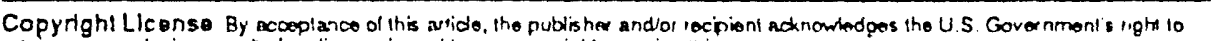
retain a nmerdusive. 1 ryahy.liee license iti and lo any ornyrigte covering this paper.

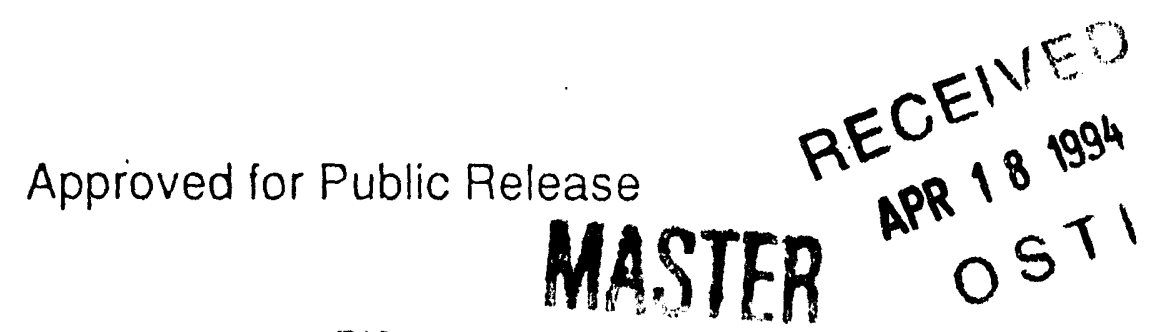




\section{LEGAL DISCLAIMER}

This report was prepared as an account of work sponsored by an agency of the United States Government. Neither the United States Government nor any agency thereof, nor any of their employees, nor any of their contractors, subcontractors or their employees, makes any warranty, express or implied, or assumes any legal liability or responsibility for the accuracy, completeness, or any third party's use or the results of such use of any information, apparatus, product, or process disclosed, or represents that its use would not infringe privately owned rights. Reference herein to any specific commercial product, process, or service by trade name, trademark, manufacturer, or otherwise, does not necessarily constitute or imply its endorsement, recommendation, or favoring by the United States Government or any agency thereof or its contractors or subcontractors. The views and opinions of authors expressed herein do not necessarily state or reflect those of the United States Government or any agency thereof.

This report has been reproduced from the best available copy.

Printed in the United States of Americe

DISCLM-2.CHP $(1.91)$ 


\section{Quantitative and Qualitative Analysis of Some Inorganic Compounds by Raman Spectroscopy}

D. R. Lombardi

C. Wang

B. Sur.
A. W. Fountain, III
J. G. Douglas
T. J. Vickers
F. L. Kohlasch
C. K. Mann
Florida State University
F. R. Reich
Westinghouse Hanford Company

Date Published

February 1994

To Be Presented at

Pittsburgh Conference

Chicago, lllinois

February 27 - March 4, 1994

Prepared for the U.S. Department of Energy

Office of Environmental Restoration and

Waste Management

(2)

Westinghouse

Hanford Company Richland, Washington 99352

Hanford Operations and Engineering Contractor for the

U.S. Department of Energy under Contract DE-AC06-87RL10930

Copyright License By acceptance of this article, the publisher andior recpient acknowledges the U.S. Government's tight to

letain a noriexclusive, royalty tlog license in and to any copyright coveting this paper. 


\title{
QUANTITATIVE AND QUALITATIVE ANALYSIS OF SOME INORGANIC COMPOUNDS BY RAMAN SPECTROSCOPY
}

\author{
D. R. Lombardi, Chao Wang, Bin Sun, A. W. Fountain, III, \\ T. J. Vickers, and C. K. Mann \\ Department of Chemistry, Florida State University, Tallahassee, FL 32306-3006 \\ F. R. Reich, J. G. Douglas and F. L. Kohlasch \\ Westinghouse Hanford Co., Richland, WA.
}

\begin{abstract}
Raman spectra have been measured for several nitrates, nitrites, sulfates, ferrocyanides and ferricyanides, both in the solid phase and in aqueous solution. Accurate locations of peak maxima are given. Limits of detection for some of the compounds are given for solutions and for solid mixtures in $\mathrm{NaNO}_{3}$. Preliminary measurements have been made on core material recovered from the storage tanks on the Hanford Site. Representative spectra are presented, showing that it is possible to observe responses of individual components from measurements made directly on untreated cores using a fiber optic sampling probe.
\end{abstract}

\section{INTRODUCTION}

This is a report of a study that is aimed at direct chemical analysis of mixtures of salts based on the Raman response of several complex anions. The target anions are sulfate, nitrite, phosphate, ferrocyanide, and ferricyanide, which will be present as minor constituents in samples that are mainly sodium nitrate as the solid, in solution, or both. In the liquid state, samples are assumed to be strongly alkaline. This sample matrix is taken because it matches the conditions that are found in the nuclear waste tanks of the Hanford site. In addition to measurements on reference materials, examples of spectra taken from tank core samples are presented.

One of the earliest systematic analytical investigations of Raman spectroscopy, that of Irish and Chen ${ }^{1}$, presents a survey of the analytical properties of a large number of organic and inorganic compounds. Included in this group are $\mathrm{NaNO}_{3}$ and $\left(\mathrm{NH}_{4}\right)_{2} \mathrm{SO}_{4}$, two of the target compounds of our investigation. The referenced paper deals mainly with problems of quantifying spectroscopic responses at a time when paper was the recording medium for measured data.

Marston ${ }^{2}$ reported a Raman-based analysis procedure for oxyanions in high-level radioactive wastes. The anions were nitrite. sulfate, chromate. phosphate and aluminate. This work also was based on application to the

"Author to whom correspondence should be directed. 
Hanford deposits. Sample conditions treated are similar to those in our work. Analytical sensitivities are expressed as ratios to the response of a similar molar concentration of nitrate.

Miller ${ }^{3}$ extended the work of Marston to cover six anions, al so presumed to be in alkaline solution. These are aluminate, chromate, nitrate, nitrite, phosphate, and sulfate. A procedure was developed for determination of these in alkaline solution based upon measurement of peak areas attributable to each analyte. This work was further extended in a study of the effects of changing sample composition on analytical response ${ }^{4}$. In this, the major thrust was to examine the effect of change in sodium ion concentration.

In the 13 years since the appearance of Reference 4, many papers dealing with the Raman behavior of some of these compounds have been publisnei. However, most of them are not relevant to this effort.

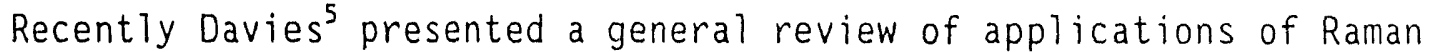
analysis in inorganic chemistry. Emphasis was placed on the capabilities that exist for distinguishing between components that are difficult to separate. such as polymorphic forms of the same compound, and on the use of low frequency bands that are often important in compounds containing heavy atoms and which are difficult to measure in the infrared. Irish and Ozeki ${ }^{6}$ have discussed the identification of inorganic species in solutions, using Raman observations with sulfate as one of the examples.

Our work builds upon the earlier efforts. However, we now benefit frum very substantial improvements in equipment that considerably extend the range of applicability of Raman measurements. Most particularly, the charge-coupled device (CCD) detector provides sensitivity comparable to that of the photomultipliers that were used in the earlier work but gives much better abscissa accuracy. Greater accuracy makes it possible to make better use of even small differences in analyte responses.

Earlier workers have stressed the point that variations in sample concentration cause variation in the position and shape of analyte peaks. Accordingly, they generally suggested the use of peak area measurements for quantitation. One consequence of this approach is it makes it difficult to deal with the many possible combinations of analytes because of spectral interference.

Our work is based on application to samples, which are mixtures of solids and liquids that contain $\mathrm{NaNO}_{3}$ as the major component and which are strongly alkaline (around pH 12). We report below on an examination of the effects of $\mathrm{pH}$ and ionic strength. We find that peak positions shift with substantial changes in ionic strength. Our results are intended to be applied to systems in which the ionic strength is substantially constant. owing to the large concentrations of $\mathrm{NaNO}_{3}$ and much smaller analyte concentrations. Under these conditions, analyte peaks do not shift in position or in shape. We demonstrate this by showing that it is possible to remove spectral contributions by the major component without distorting the contributions by a minor component. One important implication is ihat spectral interferences need not be a hindrance in analyzing these mixtures. 
WHC-SA-2098-FP

One of the useful features of Raman measurements is the ability to do direct measurements on solids; this is important in the current application. Accordingly, we have undertaken to examine the behavior of all target substarices in the solid phase. Measurements have been made with the view that they must provide the information necessary to distinguish between material in the solid and liquid phases of a single sample. We also have prepared standard curves on solid samples to determine limits of detection.

We present the spectra of the target compounds, primarily illustrating the region around $1,000 \mathrm{~cm}^{-1}$, which contains the major peaks of nitrate and sulfate and the region around $2,000 \mathrm{~cm}^{-1}$ in which the ferrocyanide and ferricyanide responses occur. Considerable care has been taken in determining peak positions because this is critical in applying reference spectra to mixture analysis.

\section{EXPERIMENTAL}

Reagents. Most reagents were obtained by purchasing the best available grade and using them as received. The exceptions were $\mathrm{Ni}_{2} \mathrm{Fe}(\mathrm{CN})_{6}, \mathrm{Na}_{2} \mathrm{NiFe}(\mathrm{CN})_{6}$ and $\mathrm{NaCsNiFe}(\mathrm{CN})_{6}$. These were prepared following procedures found in the literature ${ }^{7}$. Elemental analyses agreed reasonably well with expected values.

Spectroscopic Conditions. Measurements at Florida State University vere made with a J-Y HR640 $0.64-m$ focal length spectrograph fitted with an 1,800 -grooves/mm grating and an $1,152 \times 298$-element front-i 11 uminated CCD detector that was obtained from Princeton Instruments. This system used a fiber optic sampling arrangement that has been described 8 . A 286 - or 386 type personal computer was used as host to the detector controller, running software written by us in the $\mathrm{C}++$ language. Spectra taken at the Hanford Site were made using a Spex ${ }^{c}$ Model 500 0.5-m spectrometer, fitted with a 1,200 -grooves/mm grating and a 1,024 × 1,024 back-illuminated CCD detector. also from Princeton Instruments.

These measurements were made using the 514.5-mm line of an Ar-ion laser. Exposure times were set to produce a signal corresponding to approximately 80 percent of the range of the detector. If desired, measurement time was extended by taking replicate exposures to produce the desired signal-to-noise $(S / N)$-ratio. A considerable number and variety of measurements were involved in this work. However, in a typical case at Florida State University, the measurement might involve laser power of $200 \mathrm{~mW}$ at the sample and a total exposure time of $10 \mathrm{~min}$. Throughout, the spectrometer slit was set at $300 \mu \mathrm{ml}$. which gives a bandpass of about $7 \mathrm{~cm}^{-1}$. Measurements at Hanford were llade using a $200-\mathrm{mW}$ air-cooled laser, which produced about $100 \mathrm{~mW}$ at the sample.

Some spectra were made using a Bomem DA8 interferometer that is fitted with accessories for Raman measurements. It is used with a IVd:YAG laser from Lee Laser providing about $1 \mathrm{~W}$ at the sample and a liquid-nitrogen cooled detector. Measurements were made at $4-\mathrm{cm}^{-1}$ resolution. Spectra were calculated using the manufacturer's software, which runs on a vax computer. After this treatment, the data were converted to $145-D O S^{\circ}$ format for subsequent examination. 
Sample Geometry. With the dispersive system, solid reference materials were measured in a cylindrical container that was fitted with a glass bottom. The fiber optic probe was mounted on a micrometer-controlled stage to allow reproducible positioning, typically $1 \mathrm{~mm}$ from the glass plate and tilted at a slight angle (about 15 degrees) to minimize direct reflection into the pickup fiber. For solid samples, the container was rotated at about 1 rpm to increase the area from which the signal was collected and to minimize the effects of sample inhomogeneity. The design of this locally constructed sampling $j$ ig is illustrated in Figure 1A. Liquid samples were either measured in this container or in glass vials, in either case using the fiber optic probe.

We have also found it useful to use a rotating sample container to minimize heating and provide spatial averaging in measurements made with the Fourier Transform (FT) Raman system. This locally constructed sampling jig is illustrated in Figure 1B. It mounts directly in the sample slide holder provided by the manufacturer. The sample container is a 5 -mm diameter nuclear magnetic resonance (NMR) tube. Excitation and collection is through the side wall of the container.

Figure 1A. Rotating Sample Jig For the Dispersive Instrument.

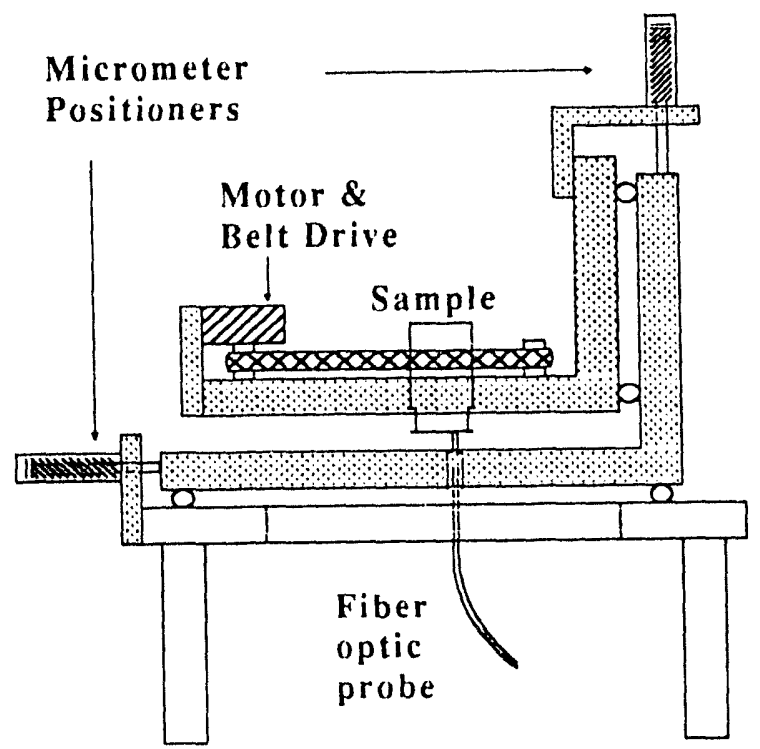

Figure 1B. Rotating Sample Jig For the Fourier Transform Instrument.

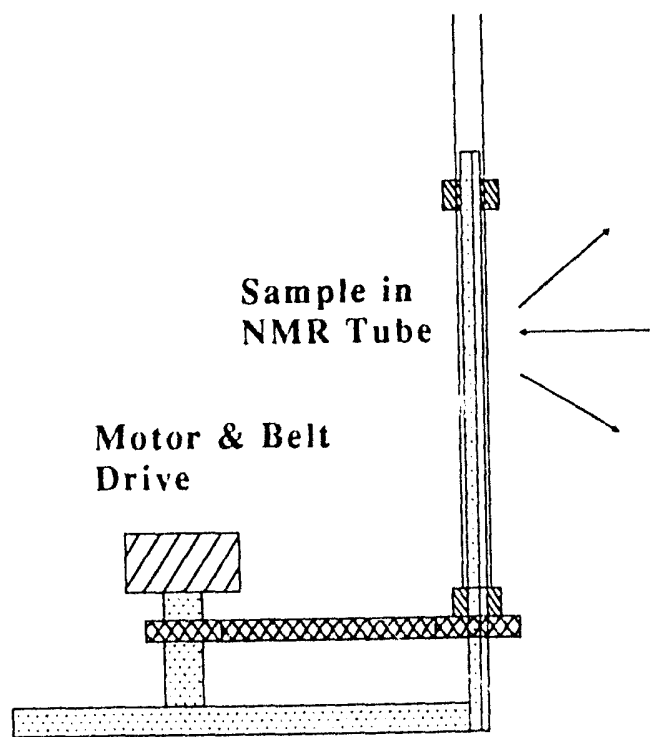

Limits of Detection. Limits of detection (LOD) were obtained for several compounds and are reported in Table I. For this purpose a series of samples with varying concentrations of analyte were prepared. From a linear regression on their spectral responses, using least-squares fitting to quantify peak sizes the slope $(S)$ and standard deviation of the intercept, $\sigma_{i}$, was calculated. LOD were taken as $3 \sigma_{i}, / S$. 
Table I. Limits of Detection.

\begin{tabular}{|c|c|c|c|}
\hline Analyte & Diluent & $\begin{array}{c}\text { Limits of } \\
\text { Detection }\end{array}$ & $\begin{array}{c}\text { Correlation } \\
\text { Coefficient }\end{array}$ \\
\hline $\mathrm{Fe}(\mathrm{CN})_{6}^{-3}$ & $1 \mathrm{MNaNO}_{3}$ & $0.17 \mathrm{mM}$ & 0.9998 \\
\hline $\mathrm{Fe}(\mathrm{CN})_{6}^{-4}$ & $1 \mathrm{~N} \mathrm{NaNO}_{3}$ & $0.11 \mathrm{mM}$ & 0.99992 \\
\hline $\mathrm{K}_{4} \mathrm{Fe}(\mathrm{CN})_{6}$ & $\mathrm{NaNO}_{3}$ & $0.6 \%$ & 0.9994 \\
\hline $\mathrm{Na}_{4} \mathrm{Fe}(\mathrm{CN})_{6}$ & $\mathrm{NaNO}_{3}$ & $3.9 \%$ & 0.994 \\
\hline $\mathrm{NO}_{2}^{-\mathrm{a}}$ & $\mathrm{H}_{2} \mathrm{O}^{-3}$ & $14.4 \mathrm{mM}$ & 0.9997 \\
\hline $\mathrm{NaNO}_{2}$ & $\mathrm{NaNO}_{3}$ & $1.12 \%$ & 0.9992 \\
\hline $\mathrm{SO}_{4}^{-b}$ & $1 \mathrm{~N} \mathrm{NaNO}_{3}$ & $2.3 \mathrm{~m} /$ & 0.9991 \\
\hline $\mathrm{K}_{2} \mathrm{SO}_{4}$ & $\mathrm{NaNO}_{3}$ & $1.4 \%$ & 0.9996 \\
\hline $\mathrm{NH}_{4}^{+c}$ & $\mathrm{H}_{2} \mathrm{O}$ & $0.13 \mathrm{M}$ & 0.990 \\
\hline
\end{tabular}

As $\mathrm{NaNO}_{2}$.

Bs $\left(\mathrm{NH}_{4}\right)_{2} \mathrm{SO}_{4}$.

${ }^{\mathrm{C} A S}\left(\mathrm{NH}_{4}\right)_{2} \mathrm{SO}_{4}$.

No internal standards were used for these measurements; LOD reflect any uncertainty in such variables as sample positioning or laser power. The preparation of homogeneous solid mixtures of known concentrations presents a problem. After considerable experimentation, we settled upon the procedure of binary dilutions starting with a 50 percent $w / w$ mixture of analyte and diluent. Samples were mixed using a vortex mixer. Measurements were made using the rotating sample holder described above.

In many cases, the factor that determined the limit of detection for solid samples was lack of sample homogeneity, rather than the actual sensitivity of the analyte response. When sample homogeneity is a problem, the detected analyte response is not proportional to its bulk concentration, causing $\sigma_{i}$ to increase. $\mathrm{Na}_{4} \mathrm{Fe}(\mathrm{CN})_{6}$ in $\mathrm{NaNO}_{3}$ was a particularly difficult case. The measured LOD is 3.9 percent. However the $S / N$ (peak height/root-meansquare) for a 1.5 percent mixture, based upon the largest of the three $C N$ compound peaks, is approximately $95: 1$. The actual LOD should be around 0.2 percent.

Data Processing. Data sets taken on the dispersive spectrometers were corrected by subtracting a dark set. The detector array pattern was removed by ratioing with a white light spectrum that had been similarly corrected for 
dark current. The silica from the fiber optic normally makes an appreciable contribution to spectra. The spectral contribution from silica alone was obtained by recording a spectrum using $\mathrm{KCl}$. If spectra were being prepared for viewing, the silica background was removed by interactive subtraction. If quantitative measurements were being made, then in some cases, the silica spectrum was included as one of the references.

For successful application of subtraction techniques to the signals produced by mixtures, it is essential that abscissa errors be sma11. This is particularly true of this work because many of the target analytes produce sharp peaks. Accordingly, along with all spectra, we recorded a neon wavelength reference. The methods that we used for establishing peak positions and for adjusting spectral positions along the abscissa have been described.9,

Some of the spectra illustrated in this report have been digitally smoothed. When this has been done, it is noted in the figure caption. The methods that were used have been described. 9.11 When any smoothing operation was carried out, care was taken to ensure that no signal components falling within the bandpass of the Raman spectrum were removed, except in the cases described below. The procedure used to determine that the information content of spectra is not compromised by smoothing is illustrated in Figure 1 of Shen, et. a1, 1992.9

The exceptions noted just above are the tank core samples which fluoresce at $514 \mathrm{~nm}$. Removing very low frequency components caused by fluorescence makes it easier to see the Raman spectra. The procedure used involved determining visually where the baseline was located. A polynomial was run through it and subtracted.

\section{RESULTS AND DISCUSSION}

Nitrate. Sodium nitrate is the major component in the tanks owing to neutralization of large amounts of nitric acid. Accordingly, it has received detailed attention. Figure $2 \mathrm{~A}$ shows the $1,000-\mathrm{cm}^{-1}$ region for saturated $\mathrm{NaNO}_{3}$ in water, solid $\mathrm{KNO}_{3}$, and solid $\mathrm{NaNO}_{3}$. Figure $2 \mathrm{~B}$ shows the corresponding regions for $\mathrm{UO}_{2}\left(\mathrm{NO}_{3}\right)_{2}, \mathrm{Nd}\left(\mathrm{NO}_{3}\right)_{3}$ and $\mathrm{La}\left(\mathrm{NO}_{3}\right)_{3}$. The positions of the peaks in this region are colfected in Table II. We believe that the uncertainties in the values are less than $0.1 \mathrm{~cm}^{-1}$.

As the previous workers pointed out, the position and width of the major nitrate peak at approximately $1,050-\mathrm{cm}^{-1}$ shifts with changes in concentration. The shift from solid $\mathrm{NaNO}_{3}$ to $\mathrm{NO}_{3}^{-}$in saturated solution is more than $16 \mathrm{~cm}^{-1}$, two orders of magnitude larger than the uncertainty in the measurement. It is easy to distinguish between solid and dissolved nitrate in samples that contain both.

There also is a shift of about $2.6 \mathrm{~cm}^{-1}$ between saturated $(\approx 7 \mathrm{M})$ and $1 \mathrm{M}$ solution. If the temperature is known, this should provide a way of approximating the concentration of a solution, based on measurement of peak positions, rather than peak intensities. 
Figure 2A. Saturated $\mathrm{NaNO}_{3}$ In Water (A), Solid $\mathrm{KNO}_{3}(\mathrm{~B})$, and Solid $\mathrm{NaNO}_{3}$ (C).

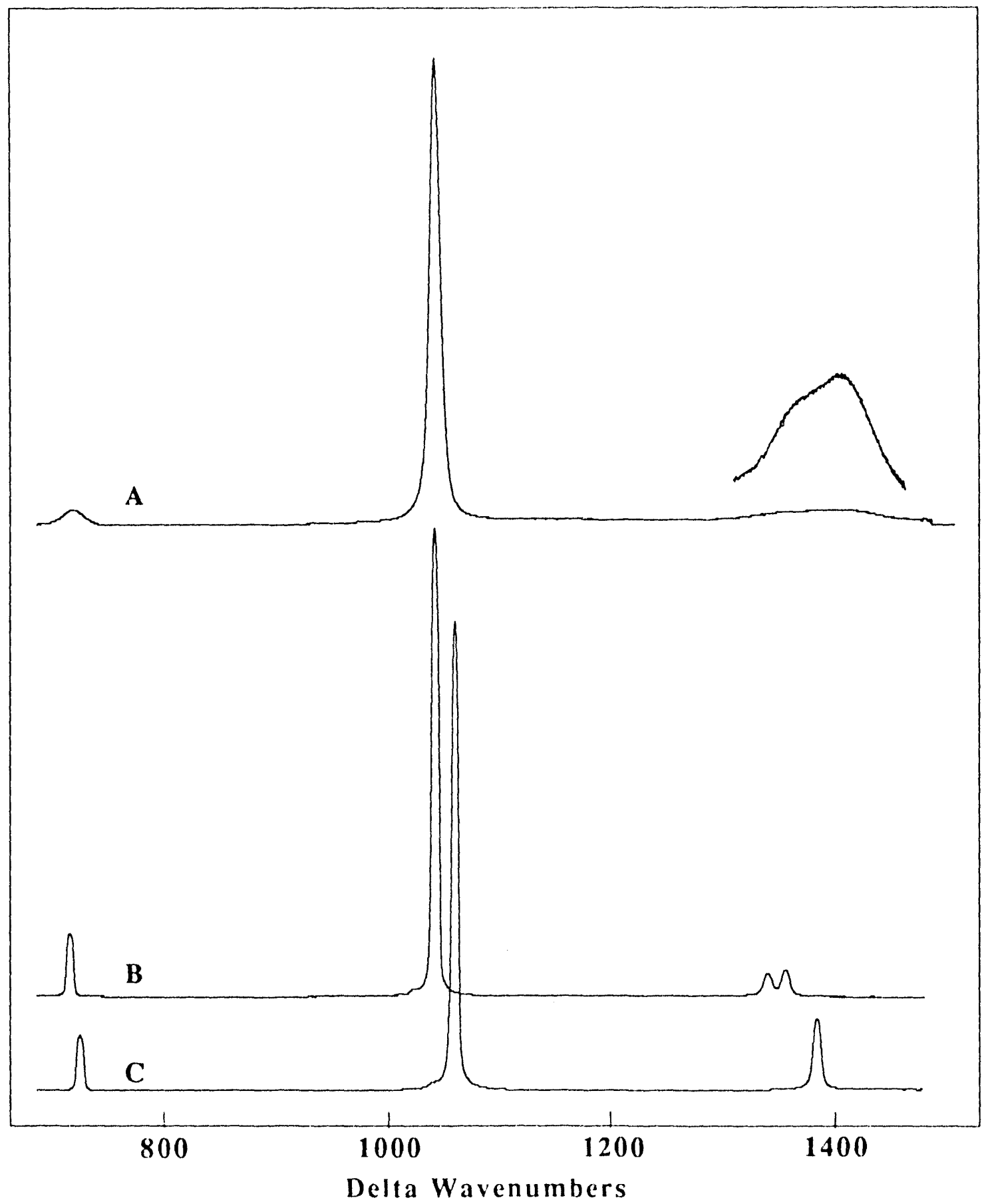


Figure 2B. Uranyl Nitrate (A), Neodymium Nitrate (B), and Lanthanum Nitrate (C).

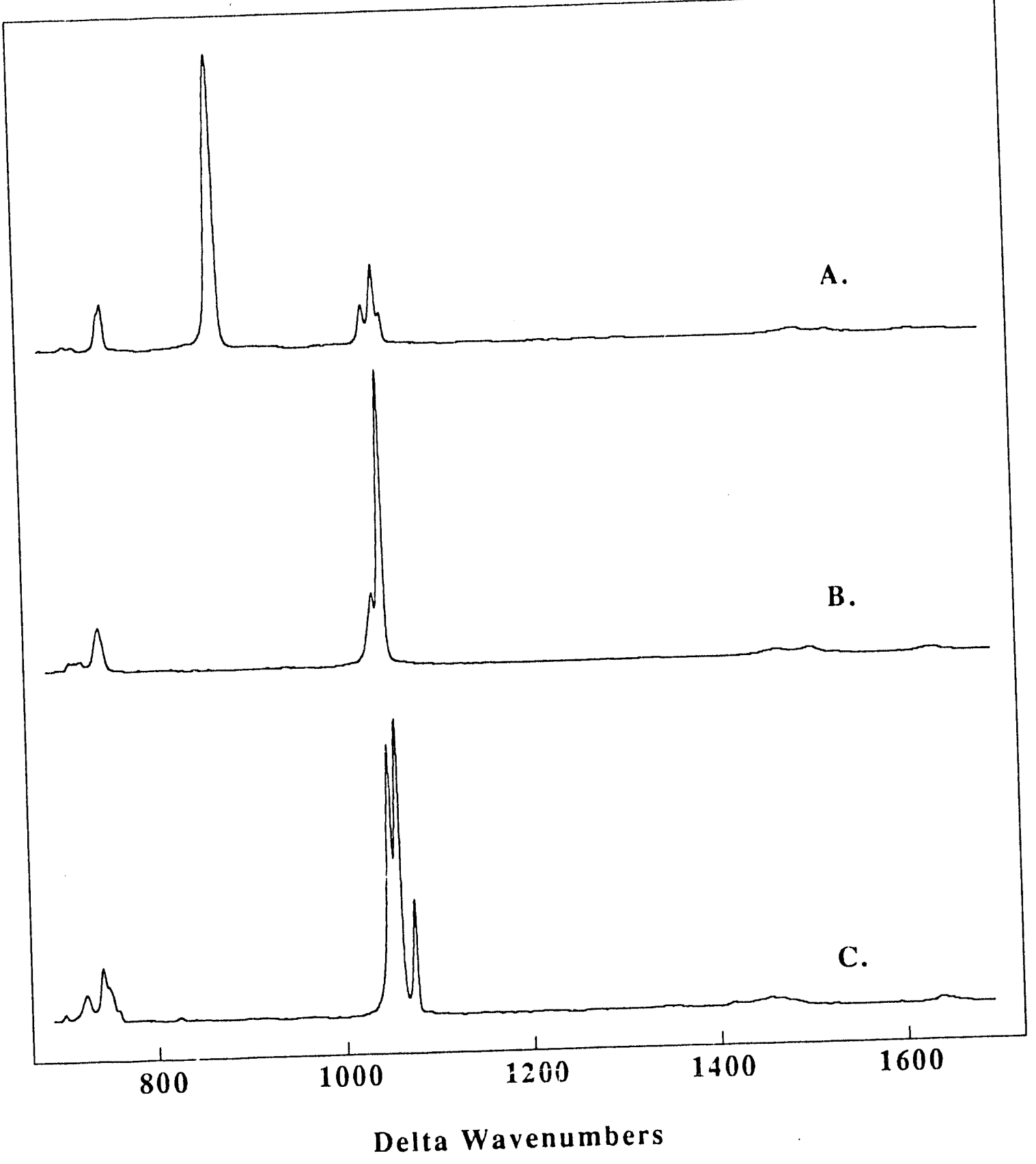




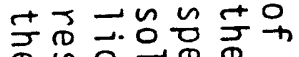

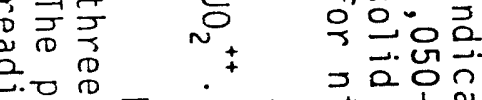

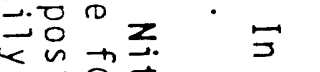

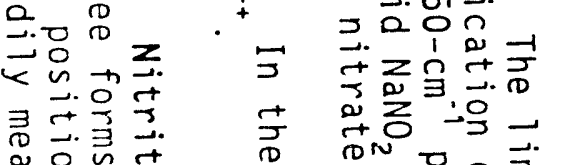

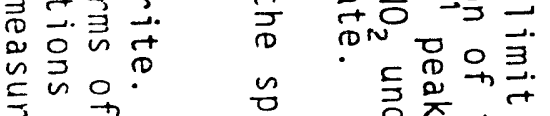

苟另了.马

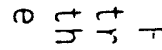

0 .

․ㅡ응

$+\mathrm{C}$

웅

品空

ב.

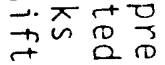

임제

紊

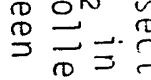

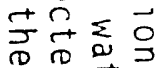

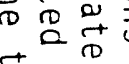

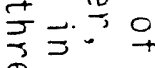

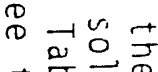

웅

跨家

$\Sigma$

引卫 $\cong$

言哭焉

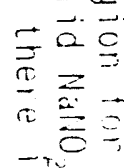

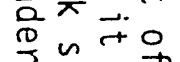

ᄀै

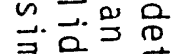

寻吅品

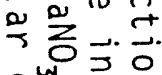

w

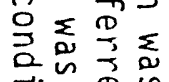

事品的

궁 $\rightarrow$ 品

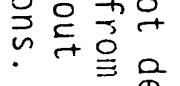

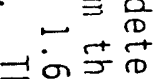

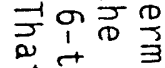

$+\vec{\exists}$

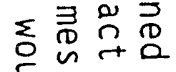

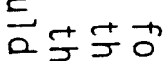

일

这另矛寻.

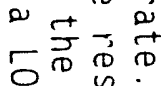

ㅁ.

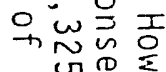

$\stackrel{1}{2} \rightarrow \frac{1}{2}$

定导总弯

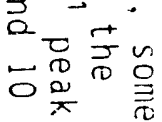

豆。

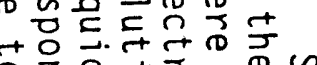

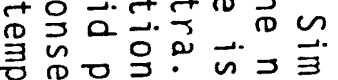

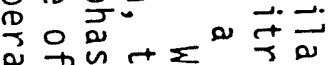

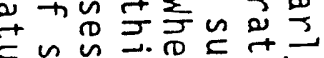

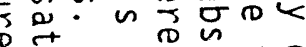

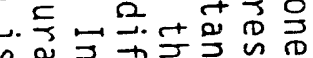

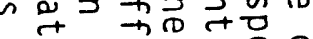

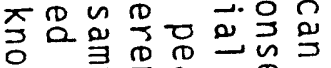

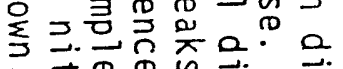
品的菠

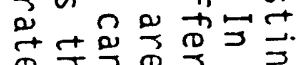

웅

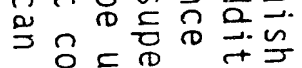

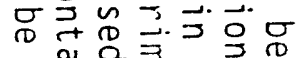

ᄃ

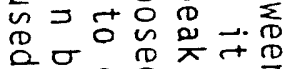

운

出留的的

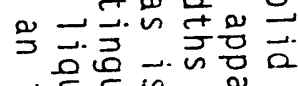

ज.

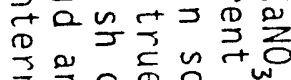

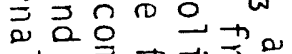

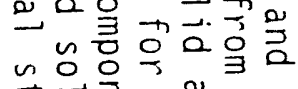

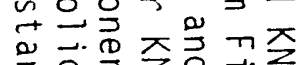

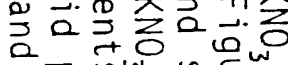

욱 क w

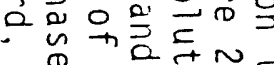

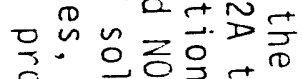

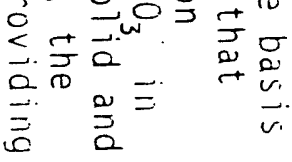

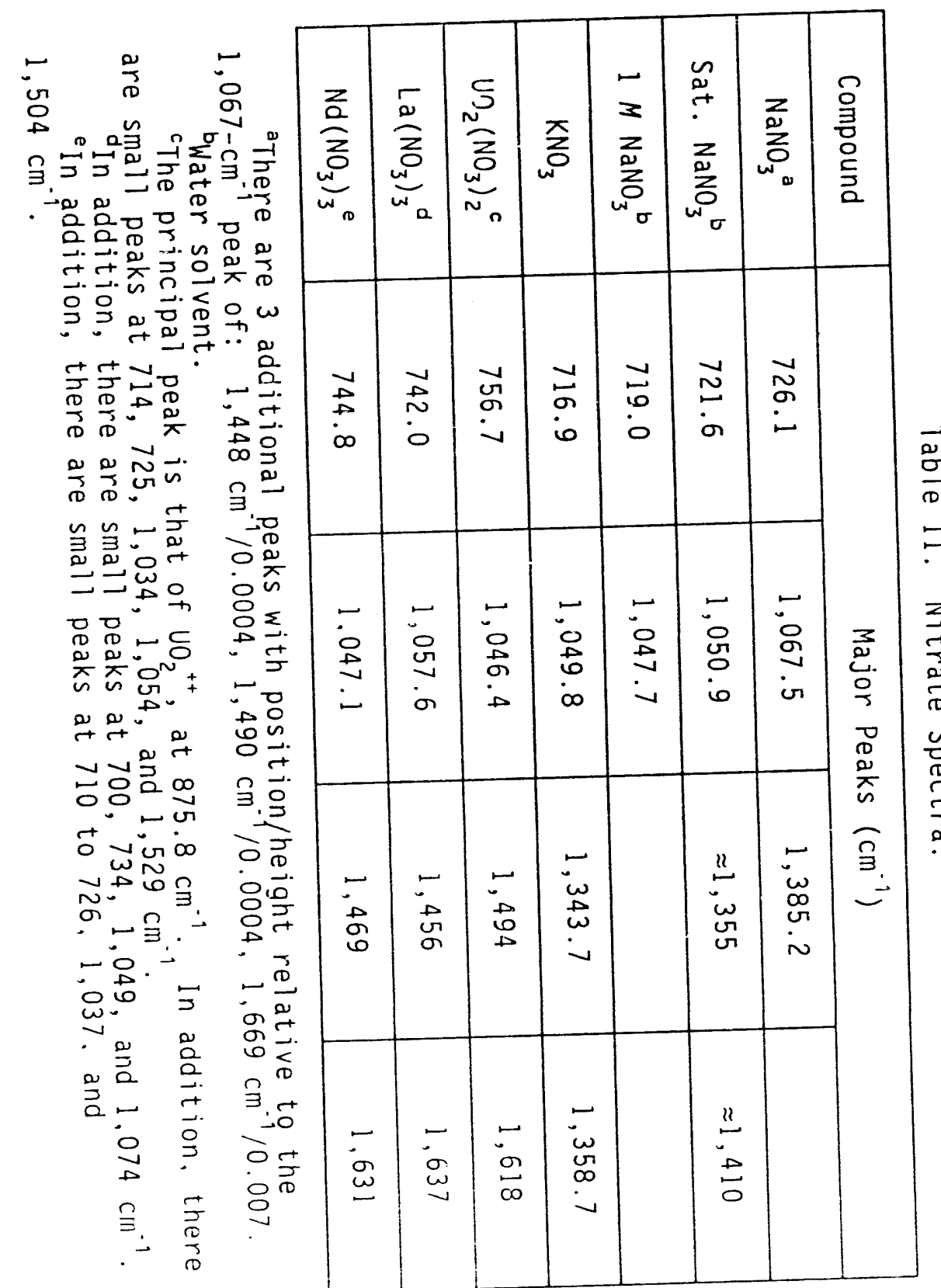


Figure 3. Saturated $\mathrm{NaNO}_{2}$ in water $(\mathrm{A})$, Solid $\mathrm{KNO}_{2}(\mathrm{~B})$, and Solid $\mathrm{NaNO}_{2}$ (C).

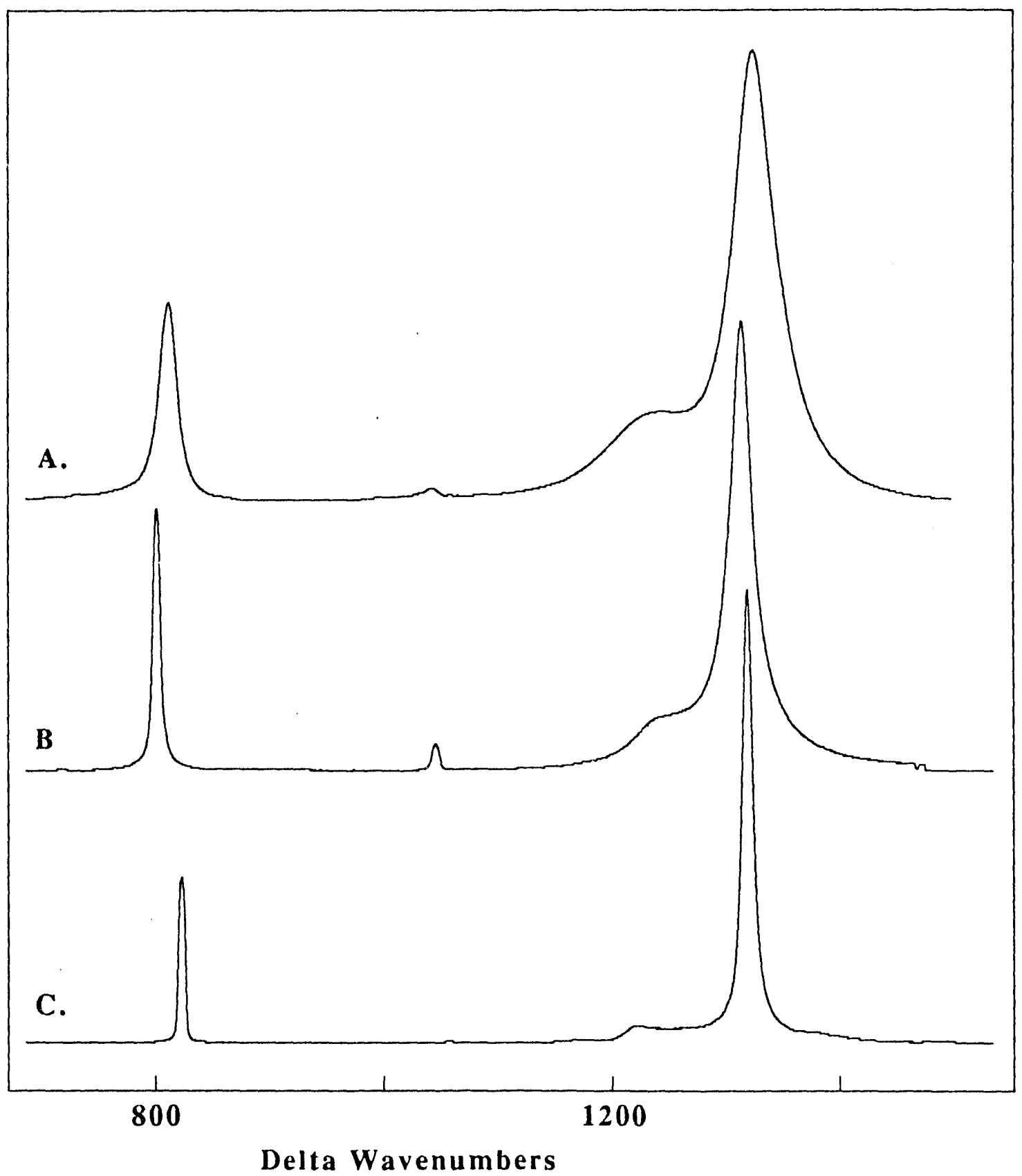

Note: The small peak near the center of each curve is caused by a nitrate impurity. 
Table III. Nitrite Spectra.

\begin{tabular}{|c|c|c|}
\hline Compound & \multicolumn{2}{|c|}{ Major Peaks $\left(\mathrm{cm}^{-1}\right)$} \\
\hline Saturated $\mathrm{NaNO}_{2}{ }^{\circ}$ & 816.9 & $1,330.5$ \\
\hline $\mathrm{KNO}_{2}$ & 806.1 & $1,320.6$ \\
\hline $\mathrm{NaNO}_{2}$ & 828.5 & $1,325.8$ \\
\hline
\end{tabular}

Water solvent.

solution species showing broader peaks. The effect of change in $\mathrm{pH}$ at values of $7,10,12$, and 14 was checked, using 10 percent $\mathrm{NaNO}_{2}$ in water. There were no significant peak shifts. For this $\mathrm{NaNO}_{2}$ concentration at $\mathrm{pH} 7$, the major peak was shifted $+0.8 \mathrm{~cm}^{-1}$ in a $1 \mathrm{MNaNO}_{3}$, and $+2.8 \mathrm{~cm}^{-1}$ in saturated $\mathrm{NaNO}_{3}$, each compared with the position in water.

Sulfate. Figure 4 presents sections of the $1,000-\mathrm{cm}^{-1}$ region for five forms of sulfate, solid $\mathrm{Na}_{2} \mathrm{SO}_{4}$, solid $\mathrm{K}_{2} \mathrm{SO}_{4}$, solid $\mathrm{BaSO}_{4}$, solid $\left(\mathrm{NH}_{4}\right)_{2} \mathrm{SO}_{4}$ and $0.1 \mathrm{M}\left(\mathrm{NH}_{4}\right)_{2} \mathrm{SO}_{4}$. The positions of the analytically important peaks are shown in the Table IV. Each of these can be distinguished from the other for both quantitative purposes. However, there is less difference in peak width between solid and solution species than is true for other ions.

Table IV. Sulfate Spectra.

\begin{tabular}{|c|c|c|c|c|c|}
\hline Compound & $\begin{array}{c}\text { Major Peaks } \\
\text { Positions } \\
\left(\mathrm{cm}^{-1}\right)\end{array}$ & \multicolumn{4}{|c|}{ Minor Peak Positions (cm $\left.{ }^{-1}\right)$} \\
\hline $\mathrm{Na}_{2} \mathrm{SO}_{4}$ & 992.9 & $1,101.4$ & $1,132.0$ & $1,153.0$ & \\
\hline $\mathrm{K}_{2} \mathrm{SO}_{4}$ & 983.6 & $1,093.6$ & $1,107.4$ & $1,145.7$ & \\
\hline $\mathrm{BaSO}_{4}{ }^{\mathrm{a}}$ & 988.6 & $1,084.8$ & $1,103.6$ & $1,142.8$ & $1,169.1$ \\
\hline$\left(\mathrm{NH}_{4}\right) \mathrm{SO}_{4}$ & 975.0 & 452 & 615 & 1,416 & 1,688 \\
\hline $\begin{array}{c}0.1 \mathrm{MH}_{4} \mathrm{SO}_{4}^{b} \\
\left(\mathrm{NH}_{4}\right.\end{array}$ & 979.9 & & & & \\
\hline
\end{tabular}

additional peaks at $453,460,616$, and $645 \mathrm{~cm}^{-1}$.

Water solvent. 
Figure 4. $\mathrm{Na}_{2} \mathrm{SO}_{4}(\mathrm{~A}), \mathrm{K}_{2} \mathrm{SO}_{4}(\mathrm{~B}), \mathrm{BaSO}_{4},{ }^{*}$ (C) $\left(\mathrm{NH}_{4}\right)_{2} \mathrm{SO}_{4}$ (D), and $0.1 \mathrm{M}\left(\mathrm{NH}_{4}\right)_{2} \mathrm{SO}_{4}{ }^{* *}$ (E).

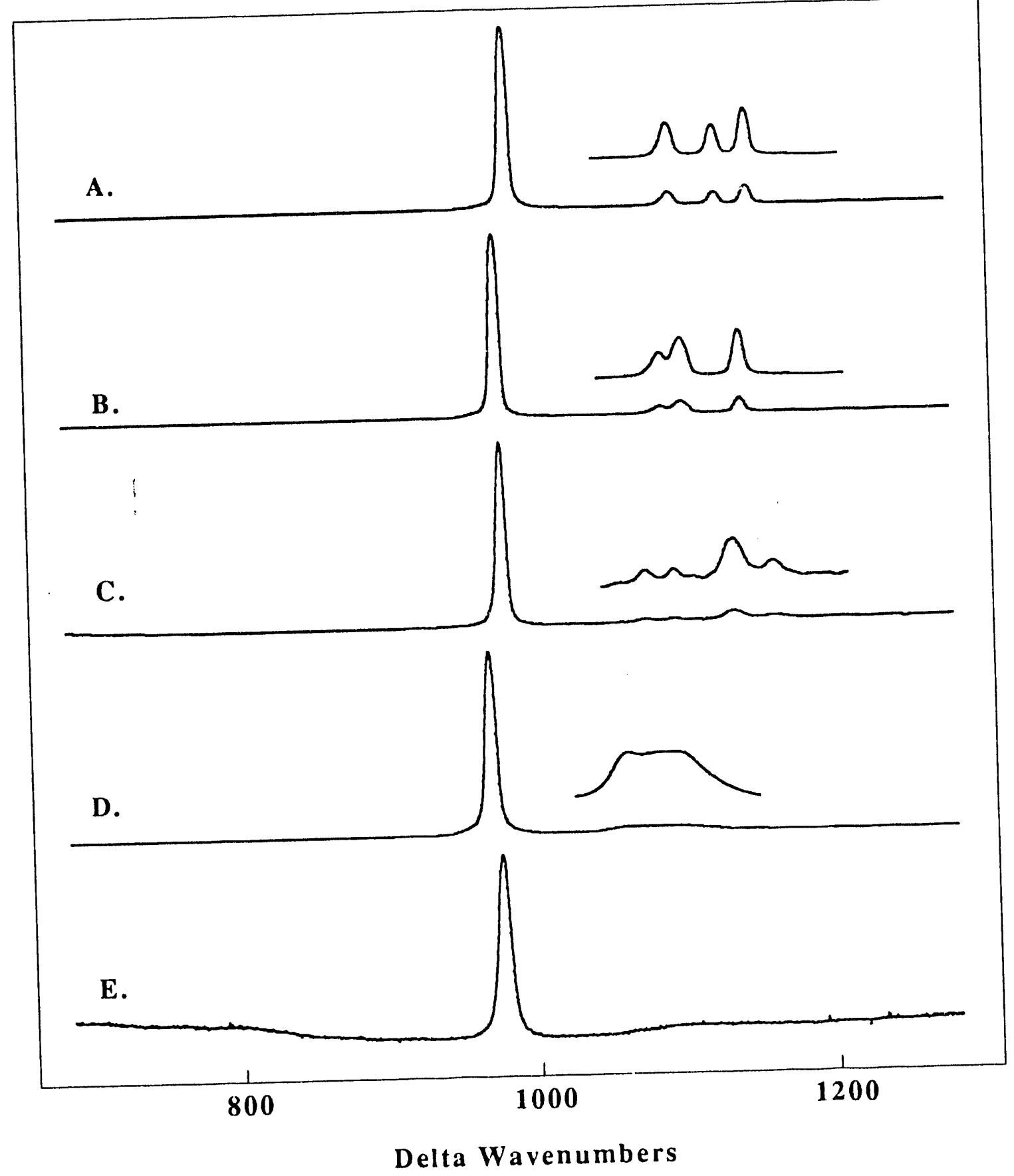

"This curve has been smoothed by digital filtering.

** This curve is scaled approximately $\times 10$ relative to the others. 
Ferricyanide. The major peaks for $\mathrm{Na}_{3} \mathrm{Fe}(\mathrm{CN})_{6}, \mathrm{~K}_{3} \mathrm{Fe}(\mathrm{CN})_{6}$ and ferricyanide ion in $1 M \mathrm{NaNO}_{3}$ solution are shown in Figure 5 . Peak positions are collected in Table $V$. With 5145- $\AA$ excitation, the solid ferricyanides showed discoloration, which was accompanied by changes in the relative heights of the two $2,100-\mathrm{cm}^{-1}$ peaks. Reduction in laser power did not entirely el iminate the problem. There also was some difficulty in measuring spectra for these species with the FT Raman system using 10645- $\AA$ radiation, but operation at lower than normal power did produce reproducible spectra.

The behavior of ferricyanide ion was checked at $\mathrm{pH} 8,10,12,13.5$, and 13.9. There was a monotonic increase in position of peak maximum as $\mathrm{pH}$ increased. However, the total range of change was approximately $0.3 \mathrm{~cm}^{-1}$, only slightly larger than the $0.2-\mathrm{cm}^{-1}$ standard deviation for this measurement. Changing from $1 \mathrm{M}$ to saturated $\mathrm{NaNO}_{3}$ caused a shift of $1.0 \mathrm{~cm}^{-1}$ towards higher wavenumbers.

Ferrocyanides. The major peaks for five forms of ferrocyanide, solid $\mathrm{Na}_{4} \mathrm{Fe}(\mathrm{CN})_{6}, \mathrm{~K}_{4} \mathrm{Fe}(\mathrm{CN})_{6}, \mathrm{NaCSNiFe}(\mathrm{CN})_{6}$ and $\mathrm{Na}_{2} \mathrm{NiFe}(\mathrm{CN})_{6}$, and ferrocyanide ion in $1 \mathrm{ANaNO}$ solution are shown in Figure 6 . Positions of the major peaks are collected in Table VI. Like ferricyanide, ferrocyanide shows a slight shift in peak position to higher wavenumbers with increasing $\mathrm{pH}$ in the range of $\mathrm{pH} 7$ to 13.9. In solution, the peaks show a shift of $+1.7 \mathrm{~cm}^{-1}$ when the electrolyte concentration is changed from $1 \mathrm{M}$ to saturated $\mathrm{NaNO}_{3}$.

Phosphate. Spectral regions containing the major peaks for $\mathrm{Na}_{3} \mathrm{PO}_{4} \cdot 12 \mathrm{H}_{2} \mathrm{O}$ and for saturated $\mathrm{Na}_{3} \mathrm{PO}_{4}$ in water are shown in Figure 7. The positions for the observed peaks for phosphate are collected in Table VII.

Waste Tank Materials. Radioactive wastes have been generated by nuclear fuel reprocessing operations at the Hanford Site for more than 40 years. Throughout this time, wastes have been stored as alkaline liquids and siurries in near-surface underground tanks. As part of efforts to reduce the volume of wastes, ${ }^{137} \mathrm{Cs}$ was removed from the supernatant in the tanks by precipitation with sodium nickel ferrocyanide. As a result of the use of several plutonium recovery processes and a variety of methods to manage the volume of stored tank wastes, the chemical composition of tanks vary widely. Tank wastes are thought to be complex mixtures of mostly inorganic salts with lesser amounts of organic materials, mostly present as salts of organic acids. Samples taken from tanks are for the most part deeply colored, presumably a result of the presence of relatively large amounts of iron- and nickel-containing compounds. Given the complexity of these materials and the usual concern about fluorescence interference, some skepticism about the utility of Raman measurements is both expected and understandable. An early test of the potential utility of the method was needed. To this end, spectra have been obtained from both nonradioactive tank waste simulants and real tank waste materials in a hot cell.

Simulants. Various materials thought to mimic tank wastes in chemical, physical, and optical properties have been made. We wished to determine the limit of detection for a target species in a deeply-colored matrix. One readily available simulant is a dark brown paste-like material. The recipe for preparation of this material includes sodium nitrate, sodium aluminate, sodium hydroxide, sodium metasilicate, ferric nitrate, sodium phosphate, calcium nitrate, magnesium nitrate, manganese (II) nitrate, and water. We 
Figure 5. Solid $\mathrm{Na}_{3} \mathrm{Fe}(\mathrm{CN})_{6}(\mathrm{~A})$, Solid $\mathrm{K}_{3} \mathrm{Fe}(\mathrm{CN})_{6}(\mathrm{~B})$," and Ferricyanide in $1 \mathrm{M} \mathrm{NaNO}_{3}(\mathrm{C})$."*

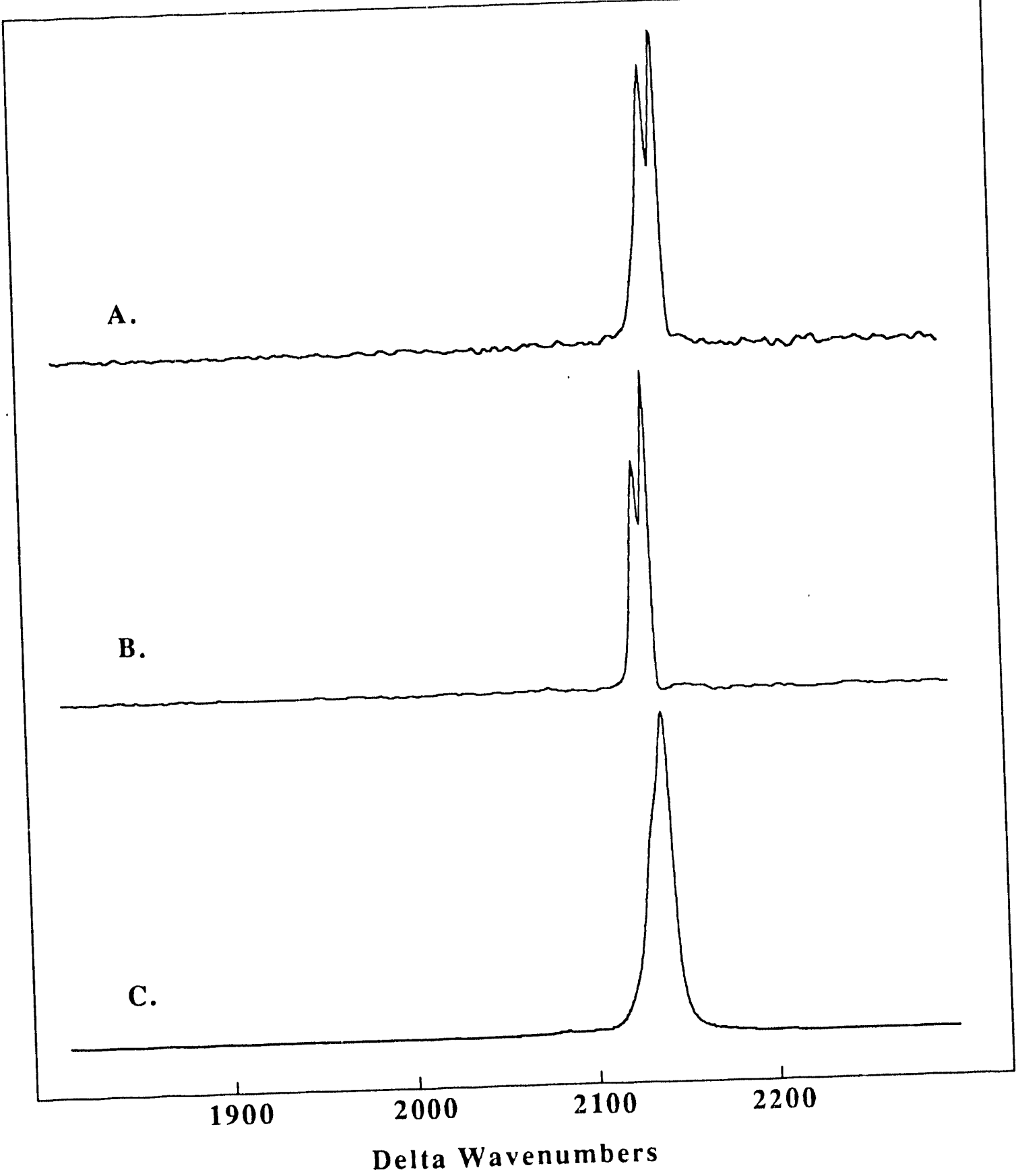

"Curves A and B were recorded with 10604- $A$ excitation using a Fourier transform instrument.

*" Curve $C$ was recorded on a dispersive spectrometer with $5145-\AA$ excitation. 
Table V. Ferricyanide Spectra.

\begin{tabular}{|c|c|c|}
\hline Compound & \multicolumn{2}{|c|}{ Peak Positions $\left(\mathrm{cm}^{-1}\right)$} \\
\hline Ferricyanide in $1 M \mathrm{NaNO}_{3}$ & $2,135.1$ & \\
\hline $\mathrm{K}_{3} \mathrm{Fe}(\mathrm{CN})_{6}{ }^{\mathrm{a}}$ & $2,129.2$ & $2,135.6$ \\
\hline $\mathrm{Na}_{3} \mathrm{Fe}(\mathrm{CN})_{6}$ & $2,139.2$ & $2,146.3$ \\
\hline
\end{tabular}

${ }^{a}$ Additional minor peaks at 124,160 , and $177 \mathrm{~cm}^{-1}$.

spiked a weighed amount of this material with a weighed amount of $\mathrm{Na}_{4} \mathrm{Fe}(\mathrm{CN})_{6}$, thoroughly mixing it by repeated cutting and folding with a spatula. To minimize the effect of any remaining sample inhomogeneity, we ran this sample in the sampling jig described previously.

Nine replicate spectra were recorded, each with an exposure time of 1 min. One such spectrum is shown in Figure 8 . Comparison of the sample spectra with the reference sper.trum for solid $\mathrm{Na}_{4} \mathrm{Fe}(\mathrm{CN})_{6}$ suggests that at least two $\mathrm{CN}$ containing components are present in the sample. The additional component may well be the $\mathrm{Fe}(\mathrm{CN})_{6}^{-4}$ anion in solution.

Least squares fitting of the $\mathrm{Na}_{4} \mathrm{Fe}(\mathrm{CN})_{6}$ reference spectrum to the sample spectra was used to quantitate the ferrocyanide signal. The limit of detection was taken to be the analyte concentration that would produce a fit value equal to three times the standard deviation, that is,

$$
L O D=3 \sigma_{\text {fit }} \times \text { wt.\%/avg fit value. }
$$

This procedure gave LOD equalling 0.25 percent $\mathrm{Na}_{4} \mathrm{Fe}(\mathrm{CN})_{5}$, assuming equal scattering by all $\mathrm{CN}$-containing species. This result compares favorably with LOD obtained in a $\mathrm{NaNO}_{3}$ matrix, suggesting little or no interference from the complex, colored matrix.

Hot Cell Measurements. Measurements on real tank wastes were carried out in a hot cell. A two-fiber probe, approximately $6 \mathrm{~m}$ in length, was installed through the hot cell wall. Outside the hot cell the probe was connected to the laser and Raman spectrometer. Inside the hot cell the end of the probe was positioned with a remote manipulator to obtain spectra from the radioactive tank waste materials.

Some results are shown in Figures 9 through 12. Figure 9 is the spectrum of a tank material in the region that contains the nitrate response, which is the prominent peak in this sample. As is true for most complex samples, these fluoresce. In Figure 9 the fluorescence component is responsible for the arching background that underlies the whole spectrum. The fluorescence component has been removed from Figures 10 through 12. 
Figure 6. $\mathrm{Na}_{4} \mathrm{Fe}(\mathrm{CN})_{6} \cdot 10 \mathrm{H}_{2} \mathrm{O}(\mathrm{A}), \mathrm{K}_{4} \mathrm{Fe}(\mathrm{CN})_{6} \cdot 3 \mathrm{H}_{2} \mathrm{O}(\mathrm{B})$, Ferrocyanide Ion, Saturated, in $1 \mathrm{M} \mathrm{NaNO}_{3}(\mathrm{C})$,

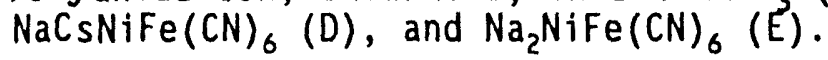

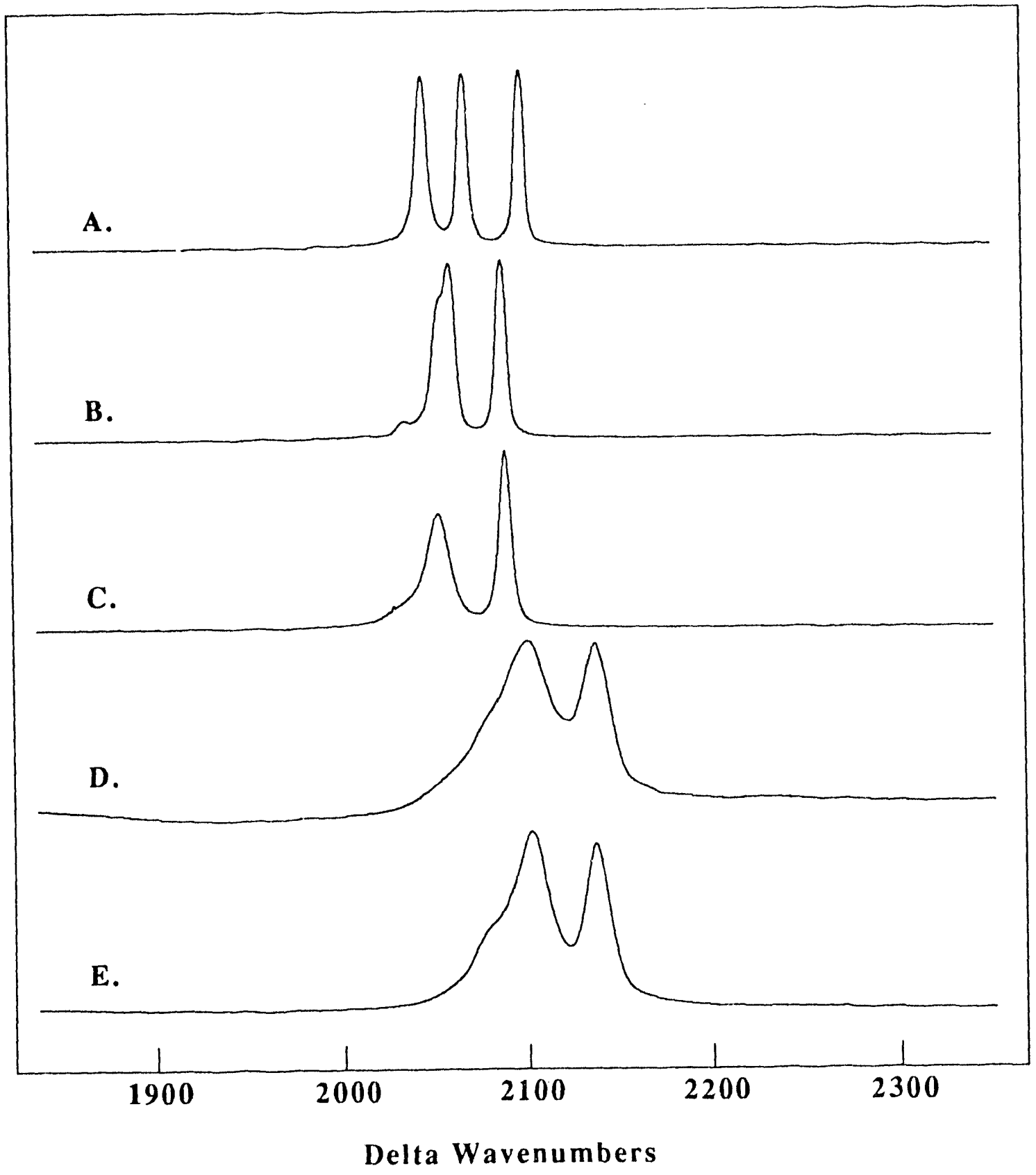


Table VI. Ferrocyanide Spectra.

\begin{tabular}{|c|c|c|c|}
\hline Compound & \multicolumn{3}{|c|}{ Peak Positions $\left(\mathrm{cm}^{-1}\right)$} \\
\hline $\begin{array}{c}\text { Ferrocyanide in l M } \\
\mathrm{NaNO}_{3}\end{array}$ & $2,056.8$ & $2,093.8$ & \\
\hline $\mathrm{NaCsNiFe}(\mathrm{CN})_{6}$ & $2,104.4$ & $2,140.8$ & \\
\hline $\mathrm{Na}_{2} \mathrm{NiFe}(\mathrm{CN})_{6}$ & $2,105.9$ & $2,140.7$ & \\
\hline $\mathrm{Na}_{4} \mathrm{Fe}(\mathrm{CN})_{6} \cdot 1 \mathrm{OH}_{2} \mathrm{O}^{a}$ & 2049.1 & $2,071.6$ & $2,102.6$ \\
\hline $\mathrm{K}_{4} \mathrm{Fe}(\mathrm{CN})_{6} \cdot 3 \mathrm{H}_{2} \mathrm{O}^{b}$ & $2,063.0$ & $2,091.4$ & \\
\hline
\end{tabular}

ander $5145-\AA$ excitation, $\mathrm{Na}_{4} \mathrm{Fe}(\mathrm{CN})_{6}$ shows changes in the spectrum. with additional peaks appearing around $2,000 \mathrm{~cm}^{-1}$. This is caused by dehydration, rather than photochemical decomposition. The changes are reversed when samples are rehydrated. There is an additional peak at $509 \mathrm{~cm}^{-1}$.

${ }^{b}$ Additional peaks at 128 and $184 \mathrm{~cm}^{-1}$.

Figure 10 shows spectra obtained for three different locations on another tank sample in the low wavenumber window containing the most prominent line of sodium nitrate. A sodium nitrate reference spectrum is shown for compdisull. There are at least six Raman features in addition to those attributable to sodium nitrate. The relative intensities of the features vary considerabl; with probe position in the sample, indicating sample inhomogeneity.

Figures 11 and 12 show spectra obtained at different positions and on different days in the same sample in higher wavenumber windows.

\section{CONCLUSION}

We conclude from this series of measurements that the fiber optic Raman system provides information useful in characterizing at least some of the tank waste materials. It is interesting to note that there are no spectral features attributable to any of the CN-containing species for which we have so far obtained reference spectra. The spectra are surprisingly rich in Raman lines. Our experience in measuring LOD suggest that these represent species present at concentrations of the order of 1 percent or greater. 
Figure 7. Saturated $\mathrm{Na}_{3} \mathrm{PO}_{4}$ in water $(A)$ and $\mathrm{Na}_{3} \mathrm{PO}_{4} \cdot 12 \mathrm{H}_{2} \mathrm{O}$ (B).

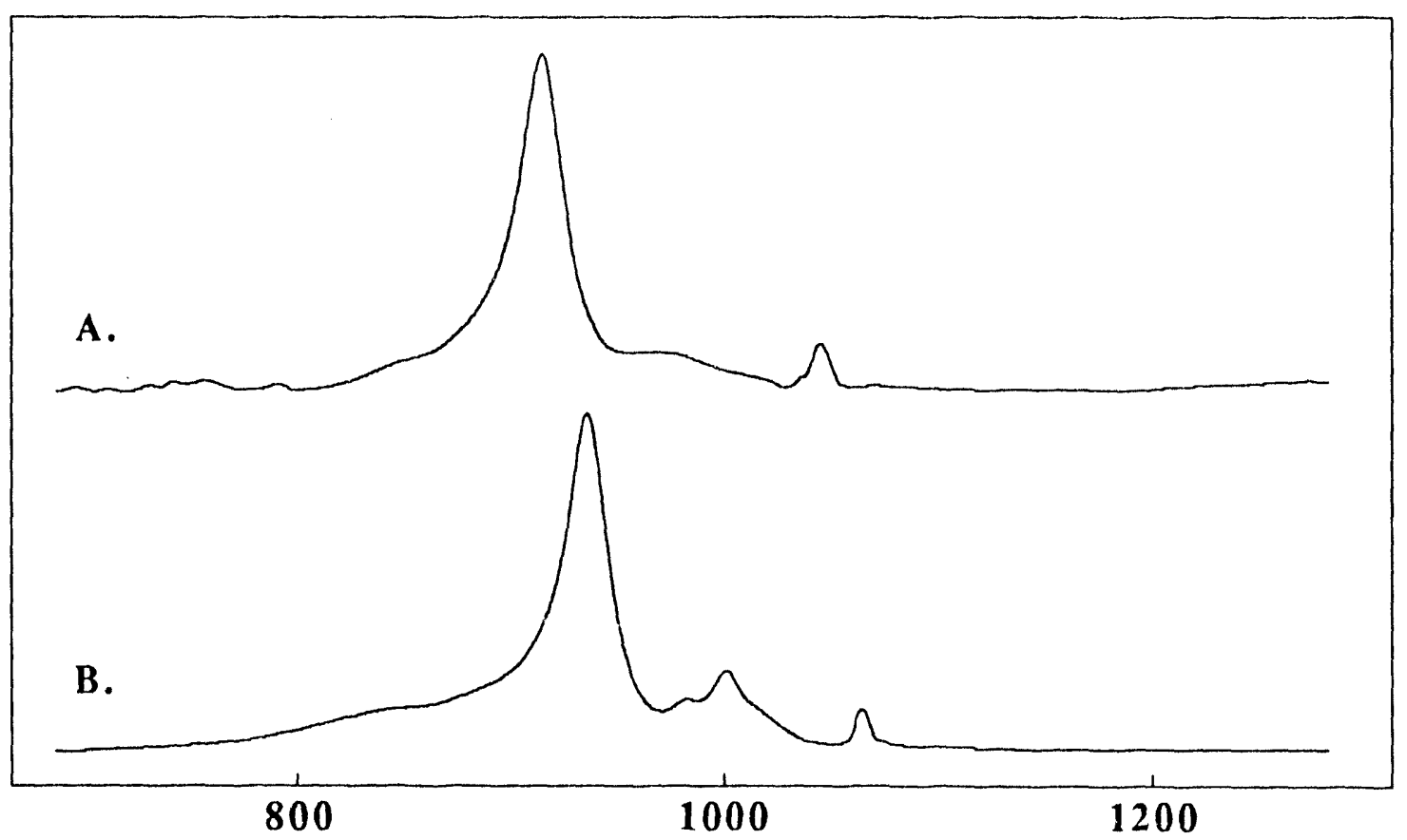

Delta Wavenumbers

Table VII. Phosphate Spectra.

\begin{tabular}{|c|c|c|c|}
\hline Compound & \multicolumn{3}{|c|}{ Major Peaks $\left(\mathrm{cm}^{-1}\right)$} \\
\hline $\mathrm{Na}_{3} \mathrm{PO}_{4} \cdot 12 \mathrm{H}_{2} \mathrm{O}^{\mathrm{a}}$ & 941.1 & $1,005.8$ & $1,069.2$ \\
\hline $\begin{array}{c}\text { Saturated } \mathrm{Na}_{3} \mathrm{PO}_{4} \\
\text { in water }\end{array}$ & 936.5 & $1,066.4$ & \\
\hline
\end{tabular}

${ }^{a}$ Additional peaks at 422 and $563 \mathrm{~cm}^{-1}$. 
Figure 8. Solid $\mathrm{Na}_{4} \mathrm{Fe}(\mathrm{CN})_{6} \cdot 1 \mathrm{OH}_{2} \mathrm{O}$ (A), Simulant Spiked With $\mathrm{Na}_{4} \mathrm{Fe}(\mathrm{CN})_{6}(\mathrm{~B})^{6}$, and simulant $(\mathrm{C})$.

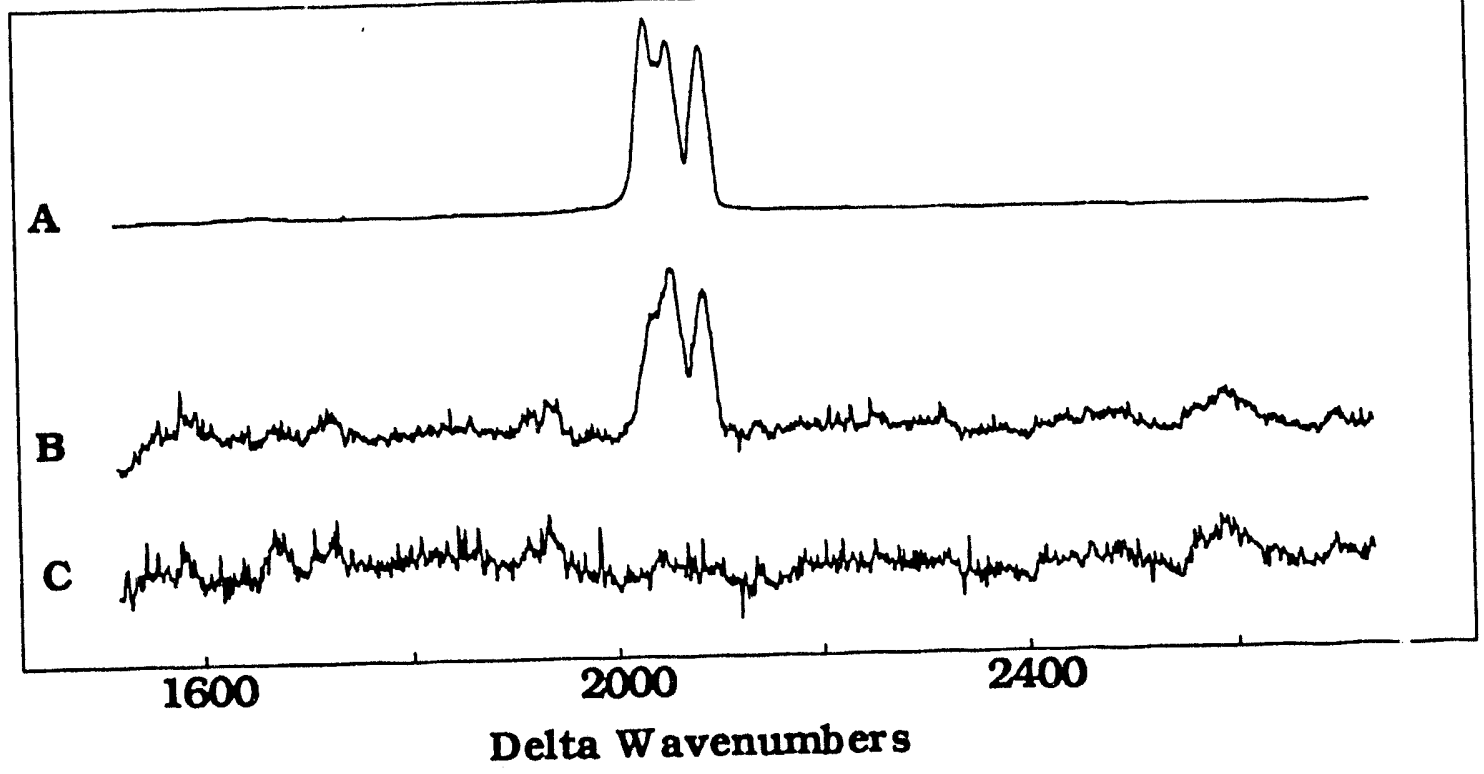

Figure 9. Nitrate Region Spectrum of Waste Tank Material. (Prominent peak is nitrate.)

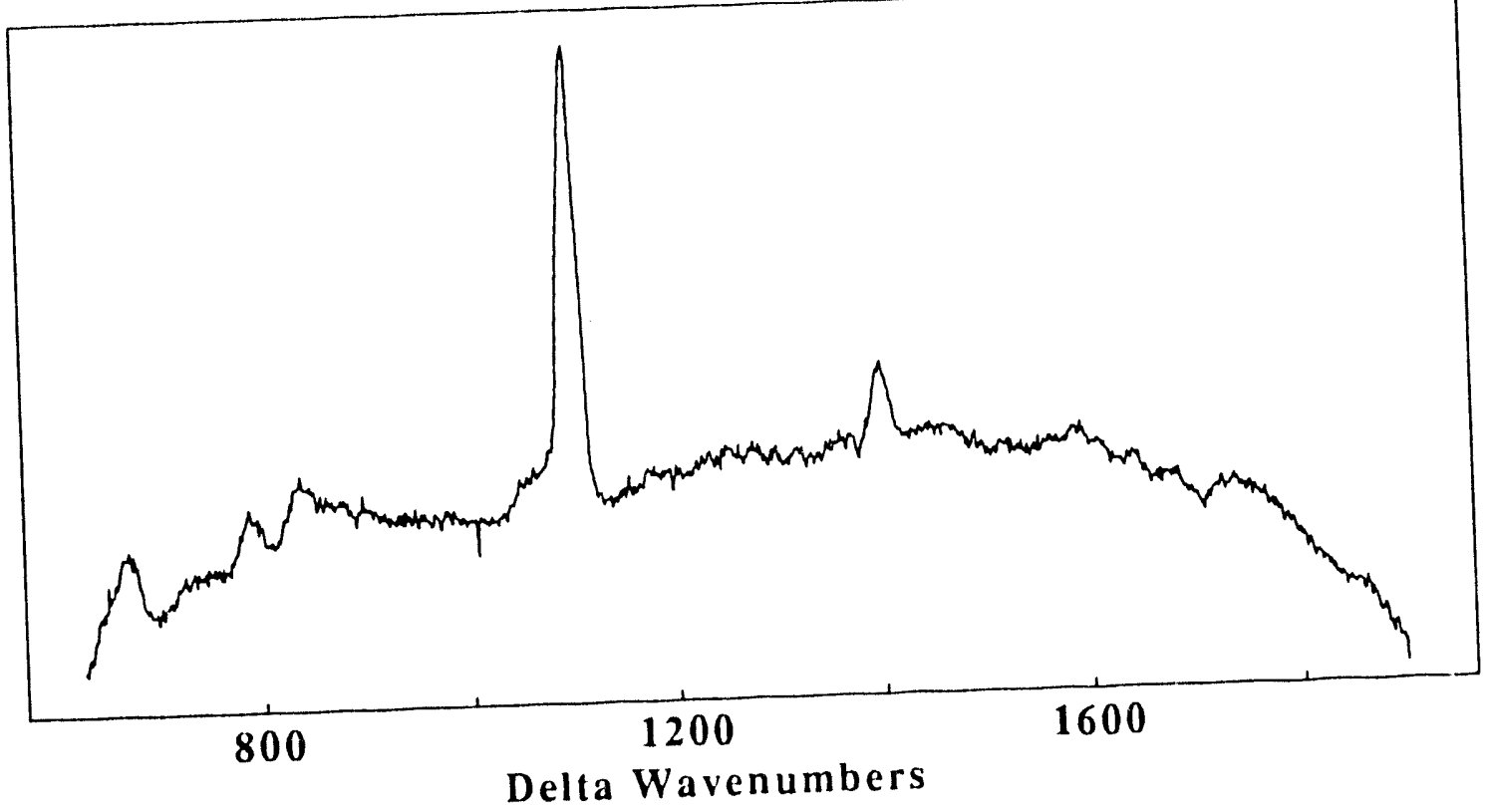


Figure 10. Tank Waste, Nitrate Region (A to C)" and $\mathrm{NaNO}_{3}$ reference spectrum (D).

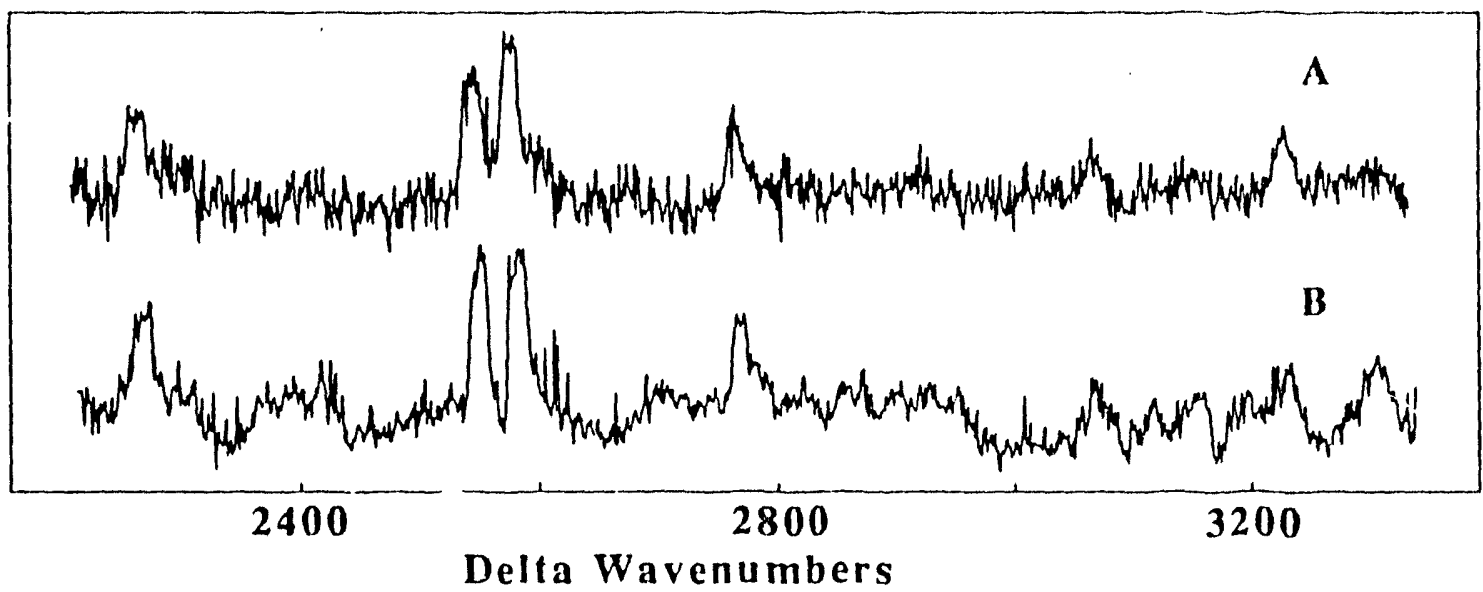

"Different locations on the same core.

Figure 11. Tank Core CN Region: One Minute Integration (A) and Ten Minute Integration With Spectra Taken on Different Days $(B)$.

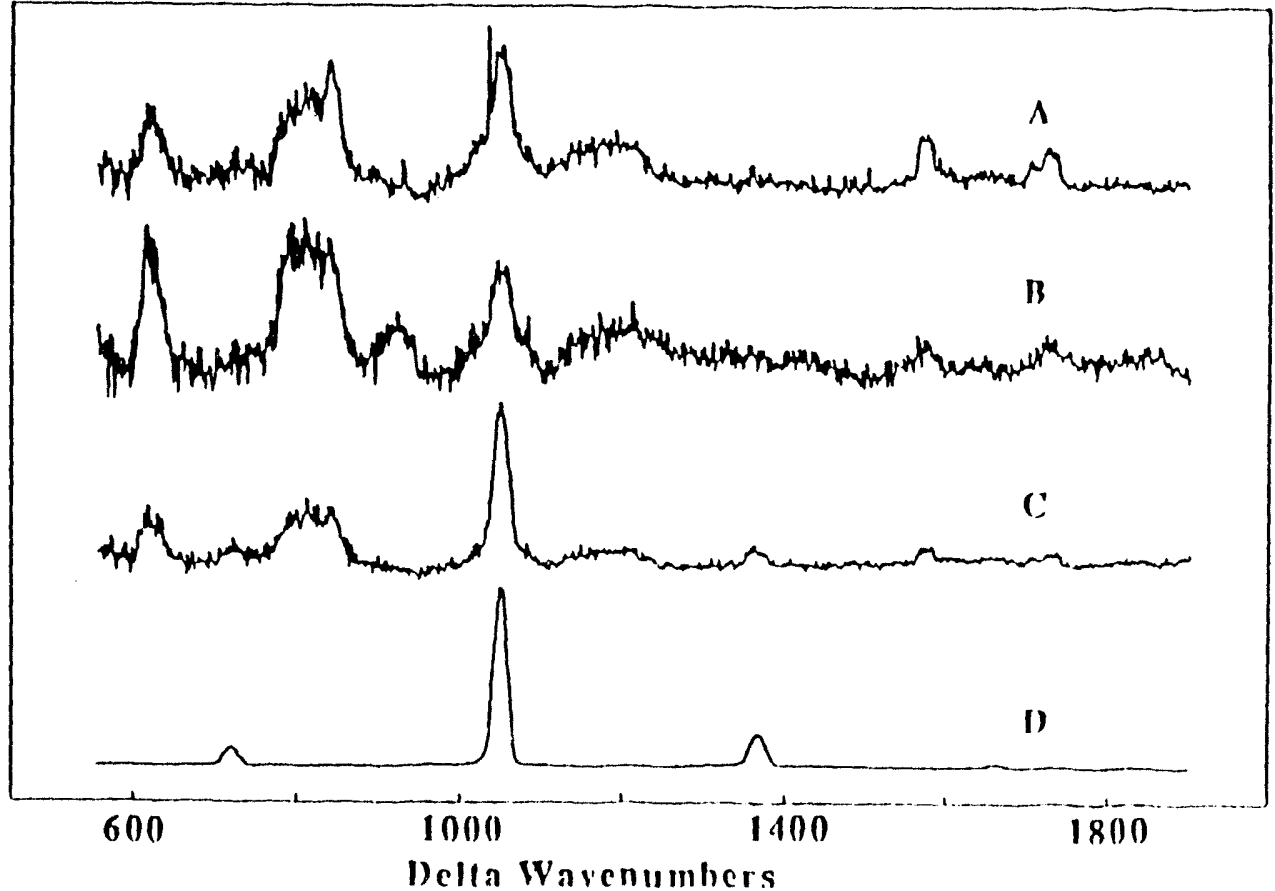


Figure 12. Tank Core $\mathrm{CH}$ Region: One Minute Integration (A) and Ten Minute Integration With Spectra Taken on Different Days $(B)$.

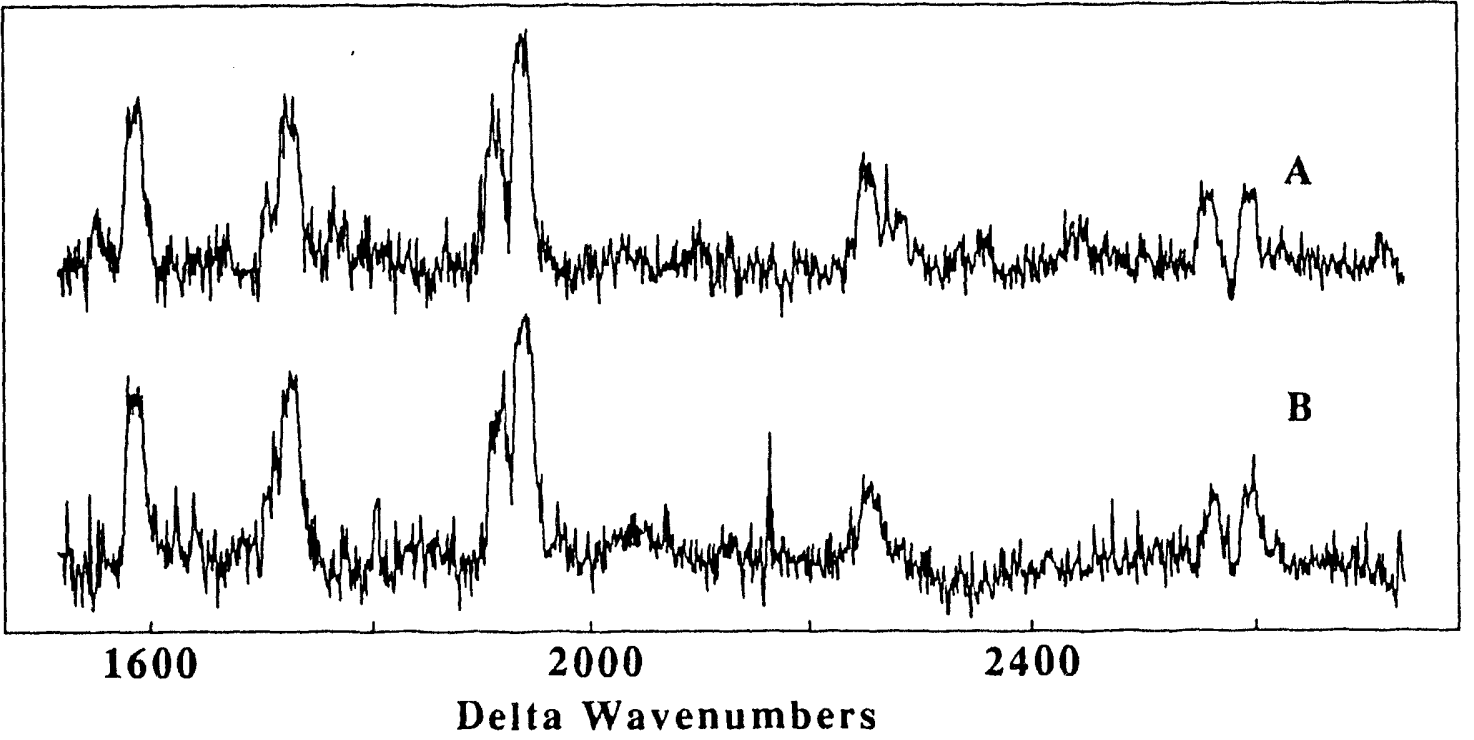

TRADEMARKS

a. Instruments S.A., Inc.

b. Princeton Sensors, Inc.

c. Spex Industries, Inc.

d. Digital Equipment Corporation.

e. Microsoft Corporation. 


\section{REFERENCES}

1. D. E. Irish and H. Chen, Appl. Spectrosc. 25, 1 (1971).

2. A. L. Marston, Nuclear Technology, 25, 576 (1975).

3. A. G. Miller, Anal. Chem. 49, 2044 (1977).

4. A. G. Miller and J. A. Macklin, Anal. Chem. 52, 807 (1980).

5. E. B. Davies, Chem. Br. 25, 607 (1989).

6. D. E. Irish and T. Ozeki, "Raman Spectroscopy of Inorganic Species in Solution," in Analytical Raman Spectroscopy, J. G. Grassel1i and B. J. Bulkin, Eds., (Wiley-Interscience, New York, 1991) Chap. 4, p. 59.

7. C. Loos-Neskovic, M. Fedoroff, E. Garnier and P. Gravereau, Talanta 31, $1133(1984)$.

8. C. K. Chong, C. Shen, Y. Fong, J. Zhu, F. -X. Yan, S. Brush, C. K. Mann and T. J. Vickers, Vibrational Spectrosc. 3, 35 (1992).

9. C. Shen, T. J. Vickers, and C. K. Mann, Appl. Spectrosc. 46, 772 (1992).

10. C.-H. Tseng, J. F. Ford, C. K. Mann and T. J. Vickers, App1. Spectrosc. In Press, 1993.

11. C. K. Mann and T. J. Vickers, Appl. Spectrosc. In Press, 1993. 
WHC-SA-2098-FP

\section{DISTRIBUTION}

Number of copies

\section{ONSITE}

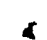

8

Westinghouse Hanford Company

J. G. Douglas

L5-55

Central Files

Information Release

Administration (3)

L8- 15

A2-26 

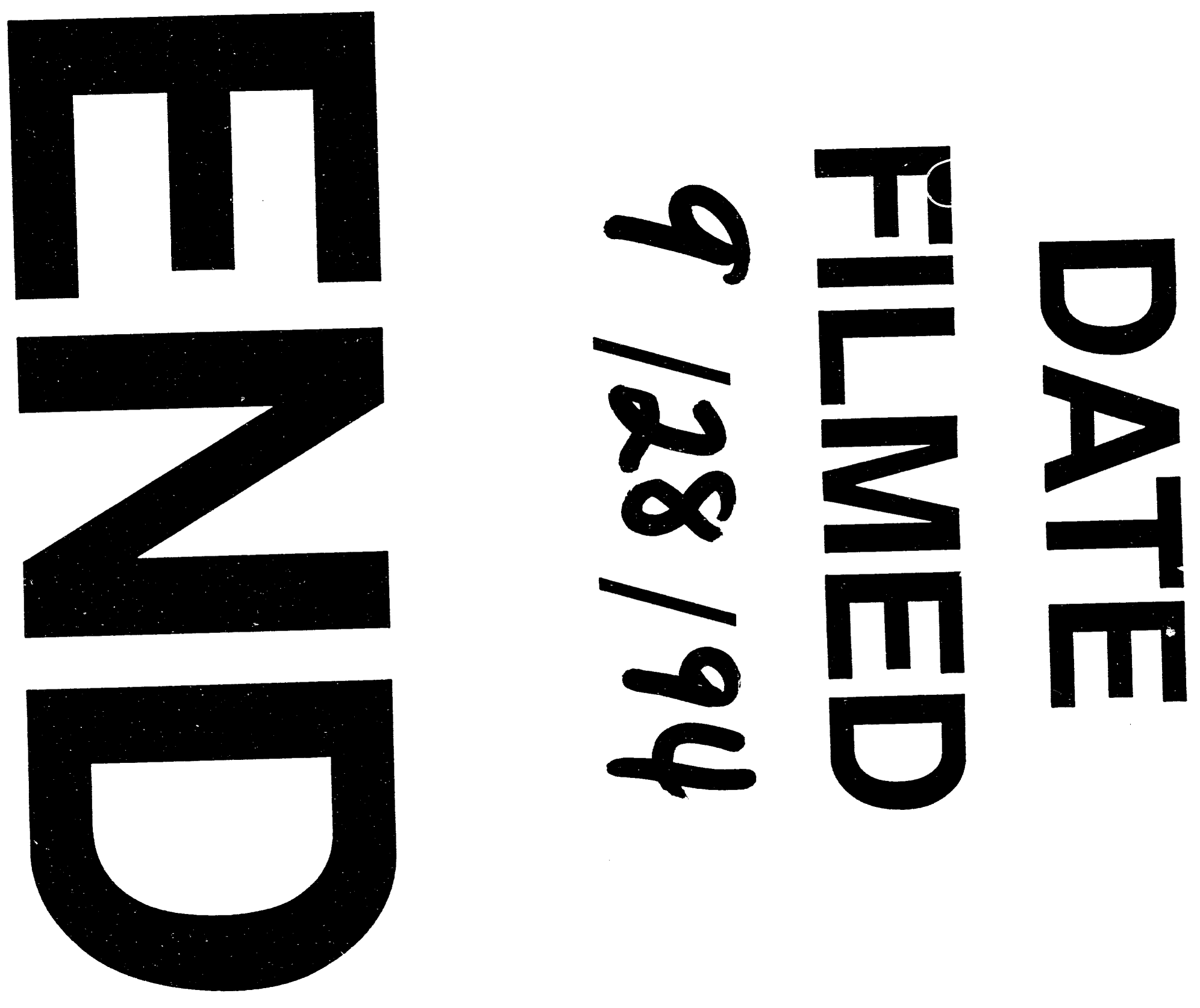


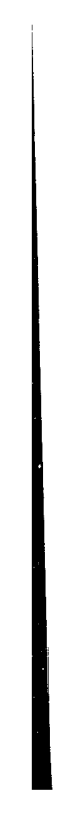

